\title{
Molecular Fingerprinting of On-Off Direction-Selective Retinal Ganglion Cells Across Species and Relevance to Primate Visual Circuits
}

\author{
Onkar S. Dhande, ${ }^{1}$ Benjamin K. Stafford, ${ }^{1}$ Katrin Franke, ${ }^{5,6 *}$ Rana El-Danaf, ${ }^{1 \star}$ Kumiko A. Percival, ${ }^{7 \star}$ Ann H. Phan, ${ }^{1}$

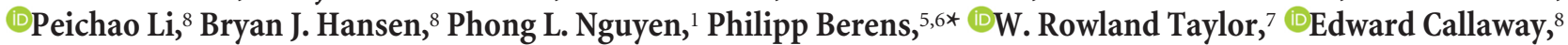 \\ Thomas Euler, ${ }^{2,3}$ and Andrew D. Huberman ${ }^{1,2,3,4}$ \\ ${ }^{1}$ Department of Neurobiology, ${ }^{2}$ Department of Ophthalmology, ${ }^{3}$ Stanford Neurosciences Institute, ${ }^{4}$ BioX, Stanford University School of Medicine, Stanford, \\ California 94305, ${ }^{5}$ Institute for Ophthalmic Research, University of Tübingen, Tübingen, Germany 72076, ${ }^{6}$ Bernstein Center for Computational \\ Neuroscience, Tübingen, Germany 72076, 7Department of Ophthalmology, Casey Eye Institute, Oregon Health \& Science University, Portland, Oregon \\ 97239, and ${ }^{8}$ Salk Institute for Biological Studies, La Jolla, California 92037
}

The ability to detect moving objects is an ethologically salient function. Direction-selective neurons have been identified in the retina, thalamus, and cortex of many species, but their homology has remained unclear. For instance, it is unknown whether direction-selective retinal ganglion cells (DSGCs) exist in primates and, if so, whether they are the equivalent to mouse and rabbit DSGCs. Here, we used a molecular/circuit approach in both sexes to address these issues. In mice, we identify the transcription factor Satb2 (special AT-rich sequence-binding protein 2) as a selective marker for three RGC types: On-Off DSGCs encoding motion in either the anterior or posterior direction, a newly identified type of Off-DSGC, and an Off-sustained RGC type. In rabbits, we find that expression of Satb2 is conserved in On-Off DSGCs; however, it has evolved to include On-Off DSGCs encoding upward and downward motion in addition to anterior and posterior motion. Next, we show that macaque RGCs express Satb2 most likely in a single type. We used rabies virus-based circuitmapping tools to reveal the identity of macaque Satb2-RGCs and discovered that their dendritic arbors are relatively large and monostratified. Together, these data indicate Satb2-expressing On-Off DSGCs are likely not present in the primate retina. Moreover, if DSGCs are present in the primate retina, it is unlikely that they express Satb2.

Key words: direction selectivity; mouse vision; primate; retina; retinal ganglion cells; visual circuits

\section{Significance Statement}

The ability to detect object motion is a fundamental feature of almost all visual systems. Here, we identify a novel marker for retinal ganglion cells encoding directional motion that is evolutionarily conserved in mice and rabbits, but not in primates. We show in macaque monkeys that retinal ganglion cells (RGCs) that express this marker comprise a single type and are morphologically distinct from mouse and rabbit direction-selective RGCs. Our findings indicate that On-Off direction-selective retinal neurons may have evolutionarily diverged in primates and more generally provide novel insight into the identity and organization of primate parallel visual pathways.

\section{Introduction}

Object motion is arguably one the most ethologically salient visual signals because the ability to detect the direction and speed of moving elements in a visual scene is critical for the survival of species from insects to humans. What cells and circuits are used to perform these computations and how have they adapted to 
meet species-specific demands? Classical direction-selective neurons are defined by their ability to respond preferentially to motion along one of the four cardinal axes of visual space: upward (superior), downward (inferior), anterior (forward), or posterior (back; Barlow and Hill, 1963; Sabbah et al., 2017). Numerous studies in primates suggest that directional motion signals in the neocortex are generated from the organization and functional properties of intracortical and/or thalamocortical inputs (Hubel and Wiesel, 1968; Schiller et al., 1976; De Valois et al., 1982; Adelson and Bergen, 1985; Hawken et al., 1988; Saul and Humphrey, 1992; Livingstone, 1998; Alonso et al., 2001). Indeed, direction-selective neurons in the primate thalamus are reported to be few in number with much weaker direction selectivity than cortical neurons (De Monasterio and Gouras, 1975; Lee et al., 1979; White et al., 2001; Xu et al., 2002; Dacey, 2004; Cheong et al., 2013). The existence of direction-selective neurons in primate retina remains to be definitively established. Therefore, it is unclear whether directional signals arise in the early stages of the primate visual system or if such signals are relevant to cortical vision.

In contrast, directionally tuned neurons are found at every level of the mouse retino-geniculo-cortical pathway. Directional motion signals are first encoded in the mouse retina by a population representing $\sim 20 \%$ of the total RGC population (Baden et al., 2016). On-Off direction-selective RGCs (DSGCs) have several well documented morphological and functional features. They respond to both increments and decrements of light (OnOff) and have bistratified dendrites that co-stratify and cofasciculate with the dendrites of starburst amacrine cells (SACs), an interneuron cell type that is critical for generating directionselective responses in RGCs (Euler et al., 2002; Weng et al., 2005; Lee and Zhou, 2006; Demb, 2007; Vaney et al., 2012). In mice, On-Off DSGCs project to the shell region of dorsal lateral geniculate nucleus (dLGN), which in turn relays directional information to the cortex (Huberman et al., 2009; Kay et al., 2011; Rivlin-Etzion et al., 2011; Cruz-Martín et al., 2014; Bickford et al., 2015). Moreover, Hillier et al. (2017) recently demonstrated that the retina influences direction selectivity in the upper layers of mouse visual cortex, although neurons in the deeper layer of the visual cortex are capable of creating direction-selective response de novo by the temporal integration of dLGN inputs (Lien and Scanziani, 2018). Regardless of their circuit origins, the direction selectivity present in mouse visual circuits allows this species to perform behavioral tasks that require perceptual discrimination of motion direction (Kirkels et al., 2018; Marques et al., 2018).

Does the absence of evidence for primate On-Off DSGCs reflect convergent evolution of motion detection in mice and primates or divergence from a common ancestral template for motion computation? To probe for On-Off DSGCs in the primate retina, we took a molecular homology/circuit approach. We identified the transcription factor Satb2 (special AT-rich sequence-binding protein 2) as a marker for mouse On-Off DSGCs. Next, we discovered that expression of Satb2 in On-Off DSCGs is conserved in rabbits, an evolutionarily distant species. Then, we found that a subset of macaque RGCs indeed express Satb2 and likely comprise a single type. Using modified rabies

W.R. Taylor's present address: School of Optometry, University of California, Berkeley, CA.

Correspondence should be addressed to either Onkar Dhande or Andrew Huberman, Department of Neurobiology, Stanford University School of Medicine, 299 Campus Drive West, Stanford, CA 94305. E-mail: odhande@stanford.edu or adh1@stanford.edu.

https://doi.org/10.1523/JNEUROSCI.1784-18.2018

Copyright $\odot 2019$ the authors $\quad 0270-6474 / 19 / 390079-18 \$ 15.00 / 0$ virus-based circuit tracing, we then discovered that the morphology of primate Satb2-RGCs is strikingly different from that of mouse and rabbit On-OffDSGCs. That prompted us to assess the full spectrum of mouse RGC types expressing Satb2-RGCs using a systematic functional classification approach based on their visually evoked calcium response properties. That approach revealed that Satb2-expressing RGCs in mice include two additional groups of RGCs: a novel population of Off-DSGCs and a population of non-directionally selective Off-sustained RGCs. Therefore, the Satb2-RGCs in macaques might reflect the evolutionary conservation of specific types of Off RGCs.

\section{Materials and Methods}

Animals. All experiments were performed in accordance with National Institutes of Health and German Government guidelines and approved by Institutional Animal Care and Use Committees at University of California-San Diego, the Salk Institute, Oregon Health \& Science University, and Stanford University.

Trhr-GFP (Huberman et al., 2009; Rivlin-Etzion et al., 2011), Drd4GFP (Huberman et al., 2009), Opn4-GFP (Lim et al., 2016), Hoxd10GFP (Dhande et al., 2013), and CB2-GFP (Huberman et al., 2008) transgenic mice were made by the GENSAT project and obtained from Mutant Mouse Resource \& Research Centers. Hb9-GFP (Stock 005029) mice were obtained from The Jackson Laboratory.

Two macaque monkeys (Macaca mulatta) were used for retrograde viral labeling of RGCs projecting to the dLGN. For all other experiments (immunohistochemistry, cell fills, and density analysis) eyes were obtained from terminally anesthetized macaque monkeys ( $M$. mulatta) used in unrelated experiments.

Histology and immunohistochemistry. Mouse retinal tissue was processed for immunohistochemistry as described previously (Tang et al., 2015; El-Danaf and Huberman, 2018). Macaque monkey retinas were immunostained in a similar manner as mouse retinas with the exception that macaque retinal tissue was fixed 4\% PFA for $30 \mathrm{~min}$ to $1 \mathrm{~h}$ and $0.5 \%$ Triton X-100 detergent was used. Rabbit retinas were fixed in 4\% PFA for $30 \mathrm{~min}$. The retinas were washed in $1 \times \mathrm{PBS}$ for $15 \mathrm{~min}$ and incubated in blocking solution (10\% normal horse serum, $0.25 \%$ Triton X-100, $0.025 \%$ sodium azide) for $2 \mathrm{~h}$ at room temperature. Rabbit retinas were then incubated in blocking solution containing primary antibodies for $2 \mathrm{~d}$ at $4^{\circ} \mathrm{C}$. Subsequently, retinas were incubated in blocking solution containing secondary antibodies for $2 \mathrm{~h}$ at room temperature or overnight at $4^{\circ} \mathrm{C}$. Following $4-5$ washes in $1 \times \mathrm{PBS}$ for $20 \mathrm{~min}$, retinas were counterstained with Hoeschst to label nuclei and coverslipped with Mowiol mounting medium.

The following primary antibodies were used: chicken anti-GFP (1: 1000, Aves Laboratories catalog \#GFP-1020, RRID:AB_10000240), rabbit anti-dsRed (1:1000, Clontech Laboratories catalog \#632496, RRID: AB_10013483), mouse anti-Satb2 (1:1000, Abcam catalog \#ab51502, RRID:AB_882455), rabbit anti-Satb2 (1:1000, Abcam catalog \#ab34735, RRID:AB_2301417), goat anti-Osteopontin (1:1000, R\&D Systems cata$\log$ \#AF808, RRID:AB_2194992), goat anti-ChAT (1:100, Millipore catalog \#AB144P, RRID:AB_2079751), guinea pig anti-VAChT (1:500, Millipore catalog \#AB1588, RRID:AB_2187981), guinea pig anti RBPMS (1:1000, PhosphoSolutions catalog \#1832-RBPMS, RRID:AB_2492226), and rabbit anti-Melanopsin (1:1000, Dacey et al., 2005). Secondary antibodies (conjugated to Alexa Fluor 488, 594, or 647) were from Invitrogen and Jackson Laboratories.

Satb2 antibody characterization. Rabbit anti-Satb2 immunogen (from Abcam): synthetic peptide conjugated to KLH derived from within residues 700 to the $\mathrm{C}$ terminus of mouse SATB2. Satb2 siRNA eliminates Satb2 as measured with this antibody in embryonic stem cells (Agrelo et al., 2009). Mouse anti-Satb2 immunogen (from Abcam): recombinant fragment corresponding to human SATB2 (C terminal). Minimal Satb2 labeling as measured with this antibody in the cortex of a conditional Satb2 knock-out mouse (Leone et al., 2015). Satb2 shRNA eliminates Satb2 as measured with this antibody in rat trophoblast stem cell line (Asanoma et al., 2012). CRISPR/Cas9-mediated Satb2 knock-out elimi- 
nates Satb2 as measured with this antibody in mouse cortex (Shinmyo et al., 2016).

Sweeney et al. (2017) recently reported that the mouse anti-Satb2 antibody recognizes both Satb2 and Satb1 using Satb2 knock-out mice cortical tissue. Consistent with Sweeney et al. (2017), we found that, in the mouse retina, only $64 \pm 2 \%$ of the cells labeled by mouse anti-Satb 2 were also labeled by rabbit anti-Satb2 $(n=2$ retinas/mice; 400 cells; postnatal day 70). All rabbit anti-Satb2-labeled cells were also labeled by mouse anti-Satb2. In the macaque retina, we found that $90 \pm 4 \%$ of cells labeled by rabbit anti-Satb2 were also labeled by mouse anti-Satb2 $(n=$ 2 retinas; 235 cells). All mouse anti-Satb2 labeled cells were also labeled by rabbit anti-Satb2.

Retinal electrophysiology. Procedures for recording mouse RGCs were similar to those described previously (Osterhout et al., 2015). Briefly, retinas were harvested and dissected in gassed $\left(95 \% \mathrm{O}_{2}\right.$ and $\left.5 \% \mathrm{CO}_{2}\right)$ Ames medium (Sigma-Aldrich) under infrared illumination. Ganglion cells were targeted for recording under infrared illumination. Presumptive On-Off cells were recorded first in a loose-patch configuration with a borosilicate glass pipettes $(4-6 \mathrm{M} \Omega$ ) filled with Ames medium (Ames and Nesbett, 1981). Upon confirmation of an On-Off light response, the cell was targeted for whole-cell recording with pipettes filled with intracellular solution containing the following (in mM): $120 \mathrm{~K}$-methane sulfonate, $10 \mathrm{HEPES}, 5 \mathrm{NaCl}, 0.1 \mathrm{EGTA}, 2 \mathrm{ATP}-\mathrm{Mg}^{2+}$, and $0.3 \mathrm{GTP}-\mathrm{Na}$, titrated to $\mathrm{pH}$ 7.3. Chemicals were purchased from Sigma-Aldrich or Tocris Bioscience.

Patterned light stimuli were generated by custom software developed in Psychophysics Toolbox and MATLAB. Stimuli were projected onto the retina using a Dell video projector (M109s DLP) custom fitted with a UV LED (NC4U134A; final emission, $398 \mathrm{~nm}$; Nichia), as described previously (Osterhout et al., 2015). The wavelength of the light stimulus is approximately equally efficient at stimulating mouse $\mathrm{M}$ and $\mathrm{S}$ cones (Borghuis et al., 2013). The receptive field center was mapped by recording responses to square-wave modulations of a 300- $\mu \mathrm{m}$-diameter spot at eight positions. In subsequent experiments, stimuli were presented as a brief contrast pulse ( $\pm 100 \%$ Weber contrast; $300-\mu \mathrm{m}$-diameter spot) or as drifting square-wave gratings (100\% Michelson contrast; $1 \mathrm{~Hz} ; 500$ $\mu \mathrm{m} /$ cycle; $650 \mu \mathrm{m}$ patch diameter) modulated against a background mean luminance.

Directional preference was determined by drifting the gratings across the receptive field of the cell in 12 directions for $4 \mathrm{~s}$ with an interstimulus interval of $10 \mathrm{~s}$. The number of spikes obtained during a presentation of the gratings in a given direction was considered the response for that direction and the circular mean of the response was calculated. The four directions were represented as $90^{\circ}$ arcs centered on each cardinal direction. The tuning of the cell was determined based upon in which arc the circular mean fell. Recorded tissue was fixed with $4 \%$ PFA and immunostained with mouse anti-Satb2 (for details, see "Histology and immunohistochemistry" section). For all other mouse experiments, rabbit anti-Satb2 was used.

Procedures for recording rabbit RGCs are described in detail previously (Percival et al., 2017). Briefly, retinas were harvested and dissected under IR illumination or dim red light and maintained in oxygenated bicarbonate-buffered Ames medium buffered to $\mathrm{pH}$ 7.4. Recordings were performed at $34-36^{\circ} \mathrm{C}$. Moving light or dark bar light stimuli were generated on a monochromatic OLED display (Emagin microdisplay; peak lambda $=519 \mathrm{~nm}, 60 \mathrm{~Hz}$ refresh rate) and focused onto the retina through a $10 \times$ Olympus water-immersion objective. Directional preference of On-Off RGCs was recorded in a loose-patch configuration by analyzing spiking responses to a drifting bar (30 to $80 \%$ Weber contrast, $150 \mu \mathrm{m}$ wide, $1 \mathrm{~mm}$ long, $1 \mathrm{~mm} / \mathrm{s}$ ) moving through the center of the receptive field in 12 directions separated by $30^{\circ}$. Recorded rabbit tissue was fixed with $4 \%$ PFA and immunostained with mouse anti-Satb2 (for details, see "Histology and immunohistochemistry" section). Rabbit anti-Satb2 was used to costain rabbit retinas with guinea pig anti-RBPMS.

Two-photon calcium imaging of mouse $R G C$ visual responses. Tissue preparation, bulk electroporation, two-photon imaging, light stimulation, and data analysis including clustering were performed as described previously (Baden et al., 2016). In brief, retinas were dissected from the eyecup, flat mounted, and then bulk electroporated with the synthetic calcium dye Oregon Green BAPTA-1 (Briggman and Euler, 2011). To record light-evoked calcium responses in ganglion cell layer somata, we used a MOM-type two-photon microscope (designed by W. Denk, MPI, Martinsried; purchased from Sutter Instruments/Science Products) combined with a DLP projector (K11, Acer) for visual stimulation Regions of interests were defined semiautomatically. The traces were projected on the response features extracted using sparse principal component analysis from the database of visual responses used in Baden et al. (2016). The extracted features were then used to assign each cell that passed the quality criterion to previously defined functional groups. First, we split direction-selective and non-direction-selective cells and then assigned them to cluster with highest posterior probability under the Gaussian mixture model fit in (Baden et al., 2016) for each of the two groups as follows:

$$
\hat{c}_{i}=\arg \max _{c} p\left(c \mid f_{i}, \mu_{c}, \Sigma_{c}\right)
$$

Where $f_{\mathrm{i}}$ is the feature representation of neuron $i$ and $\mu_{\mathrm{c}}$ and $\Sigma_{\mathrm{c}}$ are the obtained mean and covariance matrix of cluster $c$, respectively. Cells with large cell body were handled separately as described in Baden et al. (2016).

After calcium imaging, retinas were fixed and immunostained with rabbit anti-Satb2 and guinea pig anti-RBPMS (for details, see "Histology and immunohistochemistry" section). The blood vessel pattern visualized by sulforhodamine-101 (Invitrogen) during the experiments (Euler et al., 2009) was used to find the imaged region in the fixed tissue and attribution of labeled somas to recorded cells was performed manually using Image and IGOR Pro.

Macaque Satb2-RGC density quantifications. Six macaque retinas were stained with rabbit anti-Satb2 and guinea pig anti-RBPMS and $z$-stacks were taken of the ganglion cell layer using a Zeiss LSM 780 scanning confocal microscope from the fovea to the temporal edge of the retina. One retina was imaged from the nasal-to-temporal pole (see Fig. $4 C-C^{\prime \prime}$ ). For density analysis, all Satb2-expressing cells in a 1-mm-wide strip were counted. The nearest neighbor distance (NND) for each cell in a 0.56 $\mathrm{mm}^{2}$ area from 5 fields at an eccentricity of $\sim 3-5 \mathrm{~mm}$ from the fovea for 6 retinas was determined. The regularity index (also referred to as conformity ratio) was calculated by dividing the mean NND by the SD (Wässle and Riemann, 1978; Cook, 1996). Regularity index of a random distribution of cells with a density similar to Satb2-RGCs was calculated from random arrays generated in R (R Development Core Team, 2014).

Rabies virus injection into macaque dLGN. RGCs synaptically connected to geniculate neurons were labeled using modified rabies viruses ( $\mathrm{G}$ deleted, $\mathrm{Rb}-\Delta \mathrm{G}$ ) encoding fluorescent reporters as described previously (Briggs et al., 2016). Briefly, a craniotomy was made above the dLGN. The depth, size, and contralateral/ipsilateral organization of the dLGN were mapped based on responses to light flashed in the eye and recorded using a tungsten electrode. Subsequently, the coordinates were used to pressure inject small volumes of Rb- $\Delta \mathrm{G}$ encoding either GFP or mCherry at multiple depths and locations in the dLGN. Retinas and brains were harvested 6-7 d later. Live retinas were dissected and then virus-injected macaque monkeys were transcardially perfused with $4 \%$ PFA, then $4 \%$ PFA with $10 \%$ sucrose, followed by $4 \%$ PFA with $20 \%$ sucrose. Brains were removed and pieces were immersed in 30\% sucrose at $4^{\circ} \mathrm{C}$ for $1-2$ weeks and sectioned at $40 \mu \mathrm{m}$ on a sliding microtome. Brain sections were immunostained as described previously (Dhande et al., 2013). Retinas infected with Rb- $\Delta$ G-GFP were immunostained with rabbit anti-Satb2 and retinas infected with Rb- $\Delta$ G-mCherry were immunostained with mouse anti-Satb2.

Macaque RGC cell fills, $3 D$ reconstruction, and quantification. Individual RGCs were filled using sharp glass micropipettes containing Alexa Fluor 555 hydrizide (Invitrogen, A20501MP) dye by iontophoretic injection as described previously (Dhande et al., 2013; Cruz-Martin et al., 2014; El-Danaf and Huberman, 2015). Dye-filled or rabies infected (fluorescent) RGCs were imaged using a Zeiss LSM 780 scanning confocal microscope. 3D reconstructions of imaged dendrites were generated using Neurolucida software (MicroBrightField). The dendritic diameter and dendritic stratification depth of the reconstructions were calculated 
using ImageJ software as described previously (Dhande et al., 2013; Bleckert et al., 2014; El-Danaf and Huberman, 2015, 2018). Sholl analyses and the number of branch points were determined using Neurolucida explorer (MicroBrightField). For Sholl analyses, 10 concentric rings at equidistant intervals centered on the soma were placed over the dendritic field. The radius of the innermost ring (proximal to the soma) was based on the size of the total dendritic field, so that the outermost $\left(10^{\text {th }}\right)$ ring encompassed the tips of the most distal dendrites (Krahe et al., 2011; El-Danaf and Huberman, 2015). For photomicrographs in Figures 5C and $6 C$, fluorescence from sources other than the GFP-filled cell (e.g., background staining, vasculature, etc.) were digitally masked for clarity. Exemplar photomicrographs on non-masked Satb2-RGCs and corresponding 3D reconstructions are shown in Figure 7-1 (available at https://doi.org/10.1523/JNEUROSCI.1784-18.2018.f7-1).

Experimental design and statistical analysis. For functional imaging experiments, C57BL6 (wild-type) mice were used. For all other analyses, 3-week-old to 3-month-old mice were used. Mice, pigmented adult rabbits, and macaque monkeys of both sexes were used for experiments. All data are expressed as mean \pm SEM. Data were considered significant when $p<0.05$ as determined by Student's $t$ test using GraphPad Prism software.

\section{Results \\ Satb2 is enriched in specific subtypes of mouse On-Off DSGCs}

The identification of markers of cell types has greatly advanced our understanding of the organization, development, and function of the nervous system, especially in primate species (Dacey et al., 2005; Lee et al., 2016; Chandra et al., 2017; Hannibal et al., 2017; Johnson et al., 2017; Zhang et al., 2018). We hypothesized that if On-Off DSGCs were conserved across species, then perhaps the genetic pathways that define this RGC type would also be conserved (schematized in Fig. 1A).

We initiated the search in the mouse, a species in which OnOff DSGCs have been identified by electrophysiology (Weng et al., 2005; Chen et al., 2009), imaging (Baden et al., 2016), and genetic markers (Kim et al., 2008; Huberman et al., 2009; Kay et al., 2011; Rivlin-Etzion et al., 2011). To identify molecular markers selectively enriched in mouse On-Off DSGCs, we performed an immunohistochemical screen focusing on transcriptional factors and identified Satb2 as an intriguing candidate. Both the structure and function of Satb2 are highly conserved across vertebrate species (FitzPatrick et al., 2003; Sheehan-Rooney et al., 2010). Satb2 is most notable for its role in specifying cortical neuronal identity and craniofacial patterning (for review, see Leone et al., 2008; Zhao et al., 2014).

There are four basic types of On-Off DSGCs, each encoding motion along one of the cardinal axes in visual space: anterior, posterior, upward, and downward. To determine whether Satb2 was a bona fide marker for mouse On-Off DSGCs, we first stained retinas from Trhr-GFP and Drd4-GFP mice, two transgenic mouse lines in which posterior-tuned On-Off DSGCs express GFP with antibodies against Satb2. We found that nearly all posterior-tuned On-Off DSGCs express Satb2 ( 97\% Trhr-GFP RGCs; 371 cells from 3 retinas/mice, and $\sim 76 \%$ Drd4-GFP RGCs express Satb2; 545 cells from 3 retinas/mice; Fig. $\left.1 B-C^{\prime \prime}, F\right)$. By contrast, On-Off DSGCs tuned for upward motion and labeled in Hb9-GFP mice do not express Satb2 (0\% Hb9-GFP RGCs express Satb2; 727 cells from 2 retinas/mice; Fig. $\left.1 D-D^{\prime \prime}, F\right)$. Furthermore, we found that Satb2 expression was very rare in the direction-selective RGCs that comprise the image stabilization accessory optic system and that are genetically labeled in Hoxd10GFP mice (Dhande et al., 2013; 1\% Hoxd10-GFP RGCs express Satb2; 348 cells from 3 retinas/mice; Fig. $\left.1 E-E^{\prime \prime}, F\right)$. Overall, these results indicate that Satb2 is not a pan-DSGC marker, but rather labels a subset of the On-Off DSGC population. We also assessed whether other prominent RGC types express Satb2. Satb2 expression was not detected in mouse $\alpha$-RGCs in either Osteopontinexpressing $\alpha$-RGCs (Duan et al., 2015; 0\% coexpression; 943 cells from 3 retinas/mice; Fig 1-1 $B-B^{\prime \prime}, E$, available at https://doi.org/ 10.1523/JNEUROSCI.1784-18.2018.f1-1) or CB2-GFP mice (0\% Cb2-GFP RGCs express Satb2; 395 cells from 4 retinas/mice; Fig. 1-1D,E, available at https://doi.org/10.1523/JNEUROSCI.178418.2018.f1-1) in which transient Off $\alpha$-RGCs express GFP (Huberman et al., 2008). Furthermore, we found that intrinsically photosensitive RGCs (Hattar et al., 2002) labeled in Opn4-GFP mice (Lim et al., 2016) do not express Satb2 (0\% Opn4-GFP RGCs express Satb2; 800 cells from 3 retinas/mice; Fig. 1-1C$C^{\prime \prime}, E$, available at https://doi.org/10.1523/JNEUROSCI.1784-18. 2018.f1-1).

Together, these data suggest that Satb2 is highly enriched in certain subtypes of On-Off DSGCs (posterior but not upward), but whether Satb2 is expressed by the other anterior and downward subtypes of On-Off DSGCs, for which there currently are no exclusive markers (transgenic or molecular), remained unclear.

\section{Satb2 selectively marks anterior and posterior On-Off DSGCs in mice}

Next, we physiologically identified each of the four types of OnOff DSGCs that encode different cardinal directions and investigated whether they express Satb2. We performed in vitro wholecell recording and measured the responses of RGCs to motion stimuli and intracellularly dye filled the recorded cells to reveal their dendritic morphology and stratification because those features together provide unequivocal evidence of On-Off DSGC identity in mice. We confirmed the identity of recorded cells as On-Off DSGCs based on the following: (1) their responses to increments and decrements of light (On-Off responses), (2) their directional tuning, and (3) the co-stratification of their dendrites with the processes of SACs, a hallmark feature of DSGCs.

We encountered 12 posterior-tuned and 10 upward-tuned On-Off DSGCs and, after the recordings, stained them for Satb2. The majority of posterior-tuned On-Off DSGCs expressed Satb2 (9/12 cells; Fig. $\left.2 A-A^{\prime \prime}\right)$, whereas none of the upward-tuned OnOff DSGCs expressed Satb2 (0/10 cells; Fig. $\left.2 B-B^{\prime \prime}\right)$, consistent with our findings above. We found that On-Off DSGCs preferring anterior motion expressed Satb2 (5/7 cells; Fig. 2C-C $C^{\prime \prime}$, whereas downward-tuned On-Off DSGCs rarely expressed Satb2 ( $1 / 8$ cells; Fig. $2 D-D^{\prime \prime}$ ). These data reveal an unexpected level of specificity of Satb2 expression in mouse On-Off DSGCs, with expression being restricted to DSGCs encoding motion either in the anterior or posterior direction, but not in the upward or downward direction.

\section{Satb2 expression is conserved in rabbit On-Off DSGCs}

The rabbit retina has long served as a model for studying the circuit architecture and synaptic mechanisms underlying retinal direction selectivity (for review, see Vaney et al., 2012; Wei, 2018). Indeed, the first functional and structural characterization of On-Off DSGCs was reported in rabbits (Barlow and Hill, 1963; Amthor et al., 1984). Moreover, several identifying features are conserved between mouse and rabbit On-Off DSGCs, including four types of On-Off DSGCs each responding best to motion along one of the four cardinal axes and their bistratified dendrites that co-fasciculate with the processes of SACs (Vaney et al., 2012; Wei, 2018). Are these similarities also reflected at the molecular level? To answer this question, we costained rabbit retinas for Satb2 and RBPMS an RGC-specific marker (Rodriguez et al., 2014). We 


\section{A}
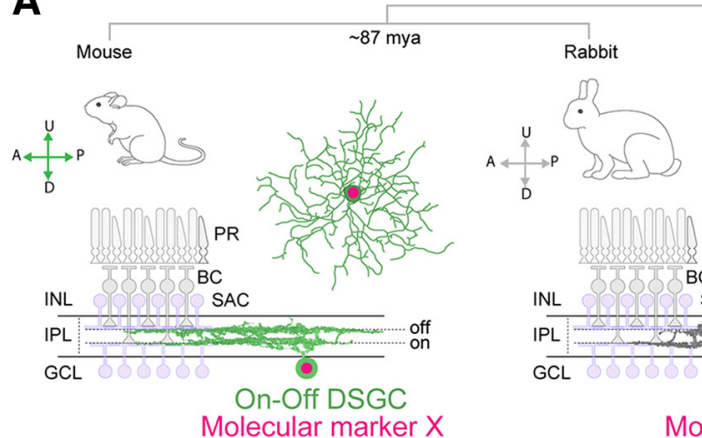

-93 mya

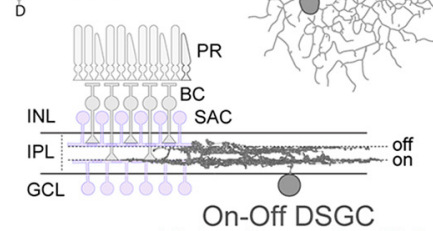

Molecular marker $X$ ?

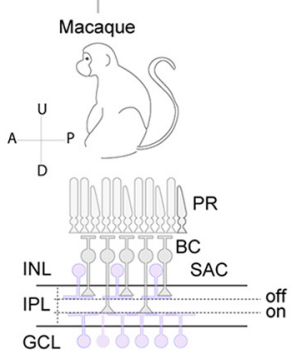

On-Off DSGC?

Molecular marker $\mathrm{X}$ ?

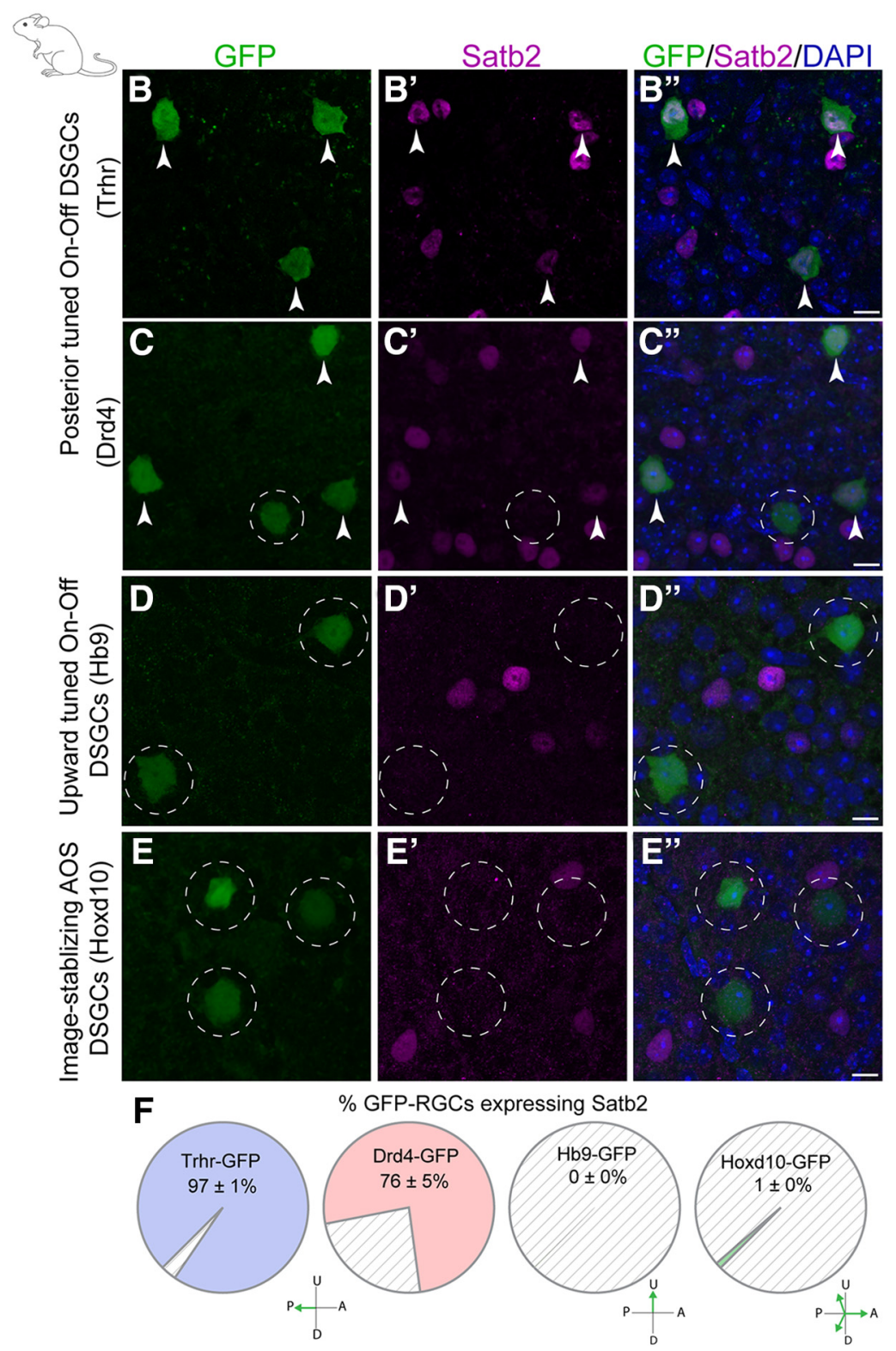

Figure 1. The vast majority of posterior-tuned On-OffDSGCs express Satb2. $A$, Schematic of logic for molecularly identifying 0n-0ffDSGCs in the mice, rabbits, and primates. $B-C^{\prime \prime}$, Virtually all

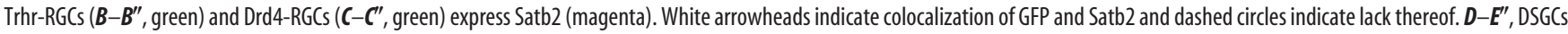
tuned for upward motion (Hb9-RGCS, D-D", green) and those DSGCs that form the accessory optic system (Hoxd10-RGCS, $\boldsymbol{E}-\boldsymbol{E}^{\prime \prime}$, green) do not express Satb2 (magenta). $\boldsymbol{F}$, Quantification of expression of Satb2 by different types of DSGCS. A, Anterior; $P$, posterior; $U$, upward; $D$, downward; PR, photoreceptors; $B C$, bipolar cell; $A C$, amacrine cell; IPL, inner plexiform layer; $G C L$, ganglion cell layer; INL, inner nuclear layer. Scale bars, $10 \mu \mathrm{m}$ in $\boldsymbol{B}^{\prime \prime}, \boldsymbol{C}^{\prime \prime}, \boldsymbol{D}^{\prime \prime}$, and $\boldsymbol{E}^{\prime \prime}$. Figure 1-1 (available at https://doi.org/10.1523/JNEUROSCl.1784-18.2018.f1-1) demonstrates the molecular analysis of Satb2-RGCS. 

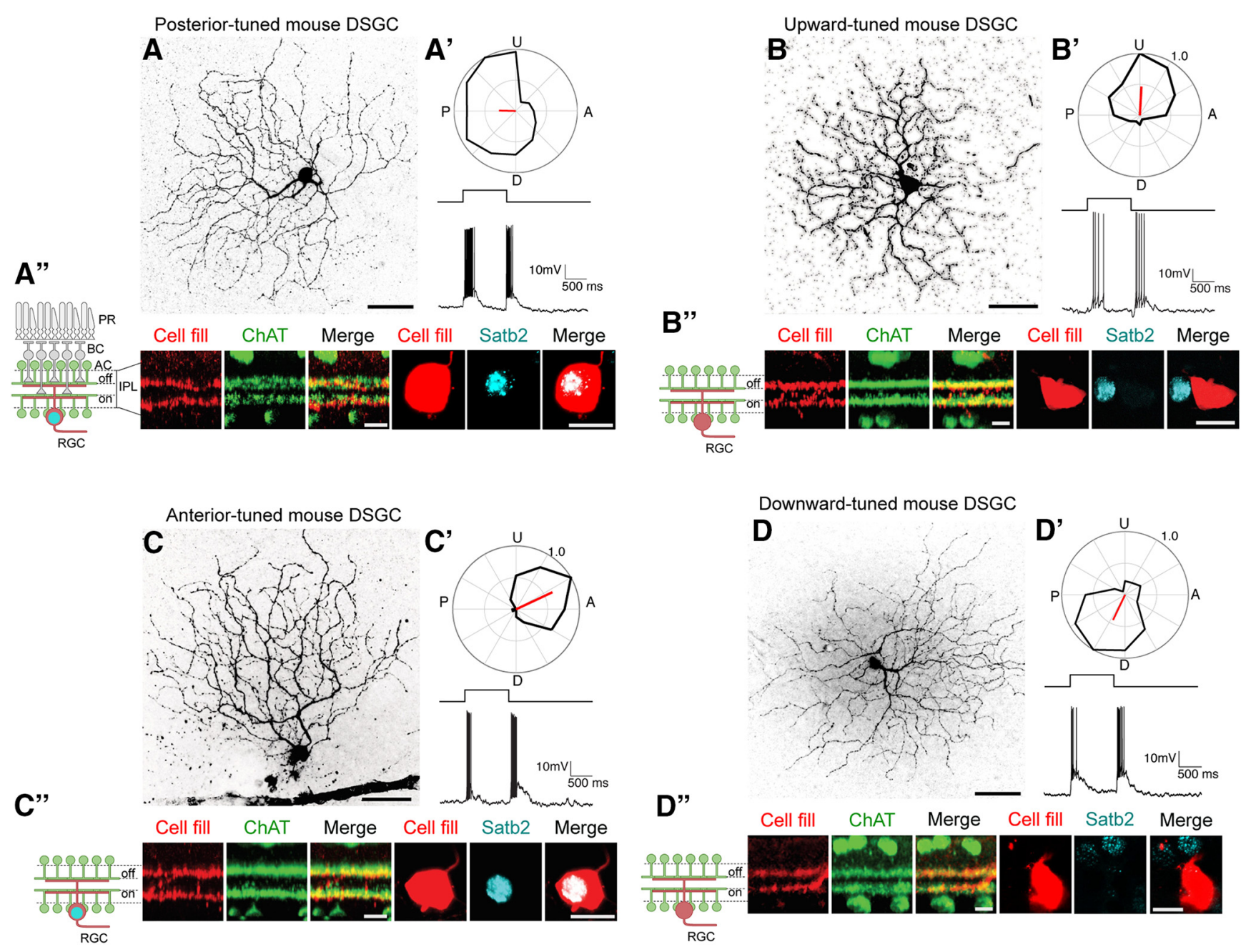

Figure 2. Satb2 is preferentially enriched in 0n-0ff DSGCs encoding motion along the anterior-posterior axis. $\boldsymbol{A}-\boldsymbol{A}^{\prime \prime}$, En face view of a dye-filled posterior-tuned 0n-0ff DSGC ( $\left.\boldsymbol{A}\right)$. The cell was identified physiologically based on directional tuning to drifting gratings $\left(\boldsymbol{A}^{\prime}\right.$, top) and based on $0 \mathrm{n}-0$-0f light responses $\left(\boldsymbol{A}^{\prime}\right.$, bottom). The dendrites of the filled cell (red) $\boldsymbol{c}^{-}$-stratify with starburst amacrine cell dendrites (ChAT, $\boldsymbol{A}^{\prime \prime}$ left, green), a hallmark of DSGCS. The recorded DSGC expressed Satb2 ( $\boldsymbol{A}^{\prime \prime}$, right). $\boldsymbol{B}-\boldsymbol{D}^{\prime \prime}$, Same as in $\boldsymbol{A}$ for an upward-tuned On-0ffDSGC that did not express Satb2 $(\boldsymbol{B})$, an anterior-tuned On-0ffDSGC that expressed Satb2 (C), and a downward-tuned On-0ff DSGC that did not express Satb2 (D). A, Anterior; $P$, posterior; $\boldsymbol{U}$, upward; D, downward; ChAT, choline acetyltransferase; PR, photoreceptor; BC, bipolar cell; $A C$, amacrine cell; IPL, inner plexiform layer; RGC, retinal ganglion cell. Scale bars, $50 \mu \mathrm{m}(\boldsymbol{A}-\boldsymbol{D}) ; 25 \mu \mathrm{m}\left(\boldsymbol{A}^{\prime \prime}, \boldsymbol{B}^{\prime \prime}, \boldsymbol{C}^{\prime \prime}, \boldsymbol{D}^{\prime \prime}\right)$.

found that $100 \%$ of rabbit Satb2 cells in the ganglion cell layer were RGCs (Fig. $\left.3 A-A^{\prime \prime}\right)$, which is identical to the pattern in mice (100\% coexpression of Satb2 and RBPMS in the ganglion cell layer; 1012 cells from 3 retinas/mice; Fig. 1-1 $A-A^{\prime \prime}, E$, available at https://doi. org/10.1523/JNEUROSCI.1784-18.2018.f1-1).

Next, we performed loose-patch recordings and identified On-Off DSGCs based on their visual responses to flashes of light and moving stimuli presented within their receptive field. As described above for mouse On-Off DSGCs, after the recordings, the dendritic morphology of rabbit DSGCs was visualized by intracellular dye fills and the recorded cells stained for Satb2 protein. In rabbits, we found that both anterior-tuned and posteriortuned On-Off DSGCs express Satb2 $(n=4 / 5$ and $1 / 1$ cells, respectively; Fig. $3 B-F$ ), which is in agreement with our findings in mice. Interestingly, however, upward-tuned and downwardtuned rabbit On-Off DSGCs appeared to also express Satb2 $(n=$ $2 / 2$ and $2 / 2$ cells, respectively).

To test the specificity of this marker for On-Off DSGCs in rabbits, we examined other RGC types that are not direction selective. We found that Off-sustained RGCs did not express Satb2 (0/5 cells; Fig. 3G-I). We also found that On-sustained, Off-transient, and On-transient RGCs did not express Satb2 (0/1,
$0 / 2$, and $0 / 1$ cells, respectively). However, due to the small sample size, we cannot conclusively state that Satb2 expression in rabbits is restricted to only On-Off DSGCs. Regardless, these data do indicate that Satb2 marks On-Off DSGCs in both mice and rabbits. In mice, Satb2 is restricted to anterior-tuned and posteriortuned On-Off DSGCs, whereas in rabbits, the expression of Satb2 extends to On-Off DSGCs tuned for each of the four cardinal directions.

\section{Primate Satb2-RGCs comprise a single RGC type}

The retinas of Old World primates possess several unique architectural and functional features not found in mice and rabbits, such as a foveal pit and high acuity trichromacy. However, there are also many features conserved among primate, murine, and lagomorph retinas (for review, see Wässle, 2004; Euler et al., 2014; Priebe and McGee, 2014; Dhande et al., 2015). Indeed, at a molecular level, human and mouse RGCs express many of the same transcription factors (Sluch et al., 2015; Langer et al., 2018).

Because we found that Satb2 is a marker for mouse and rabbit On-Off DSGCs (Figs. 1, 2, 3), we searched for the presence of Satb2-expressing RGCs in the primate retina. We were particularly interested in determining whether, if present, Satb2- 
expressing neurons in the primate retina are RGCs and, if so, whether their morphology and connectivity are similar to On-Off DSGCs in mice and rabbits. We co-immunostained flat-mounted macaque retinas for Satb2 and RBPMS and found that, indeed, Satb2-expressing neurons are present and that all of the Satb2expressing cells in the ganglion cell layer of the primate retina were RGCs $(n=289$ cells, Fig. $4 B-B^{\prime \prime}$ ). This result is consistent with our Satb2/RBPMS staining results in mice and rabbits.

RGC density, both at the level of all RGCs and as individual types, is significantly higher in the macaque fovea than in the periphery (Perry and Cowey, 1985; Wässle et al., 1989; Silveira and Perry, 1991; Dacey et al., 2005; Crook et al., 2008). This, in turn, is reflected by a relatively larger central areal representation of the fovea in the visual cortex that gives rise to higher acuity for central versus peripheral vision. Therefore, next, we examined the density profile of Satb2-RGCs by staining flat-mount retinas for Satb2 and counting the number of Satb2-RGCs located within a 1-mm-wide strip spanning from the temporal to the nasal pole of the retina (Fig. $4 C-C^{\prime \prime}$ ). We found that the density of Satb2-RGCs scales inversely with eccentricity (distance from the fovea), with a peak density of $\sim 108$ Satb2$\mathrm{RGCs} / \mathrm{mm}^{2}$ near the fovea to $\sim 12$ Satb2 $\mathrm{RGCs} / \mathrm{mm}^{2}$ in the far periphery $(>9 \mathrm{~mm}$ from the fovea; Fig. 4D). These density measurements indicate that, in primates, Satb2-RGCs comprise 1-2\% of the total RGC population (Wässle et al., 1989).

The relatively low overall density of Satb2-RGCs suggests that they may represent an individual RGC type. One distinguishing feature of individual RGC types is that their somas are often nonrandomly distributed to form a "regular" mosaic pattern, especially in primates (Wässle et al., 1981; Cook, 1996). Therefore, we analyzed the spatial distribution of primate Satb2-RGCs. Our analysis of the NND revealed that Satb2-RGCs do in fact form a relatively regular mosaic, with a mean distance of $\sim 70 \mu \mathrm{m}$ between Satb2-RGCs (Fig. 4E). We also computed the regularity index (NND divided by 1 SD), a measure of the spatial regularity of the cellular mosaic, in which an index of 1.81 indicates a random array (see Materials and Methods) and increasing index value indicates an increasingly regular mosaic pattern. Satb2-RGCs have a regularity index of 2.24, which is significantly different from the regularity index of a random array with a similar density $(p=0.000039)$. The regularity index of Satb2-RGCs is comparable to the regularity index of the previously studied parasol RGCs (On and Off) and melanopsin RGCs (inner and outer; 2.6 and 2.4, respectively,
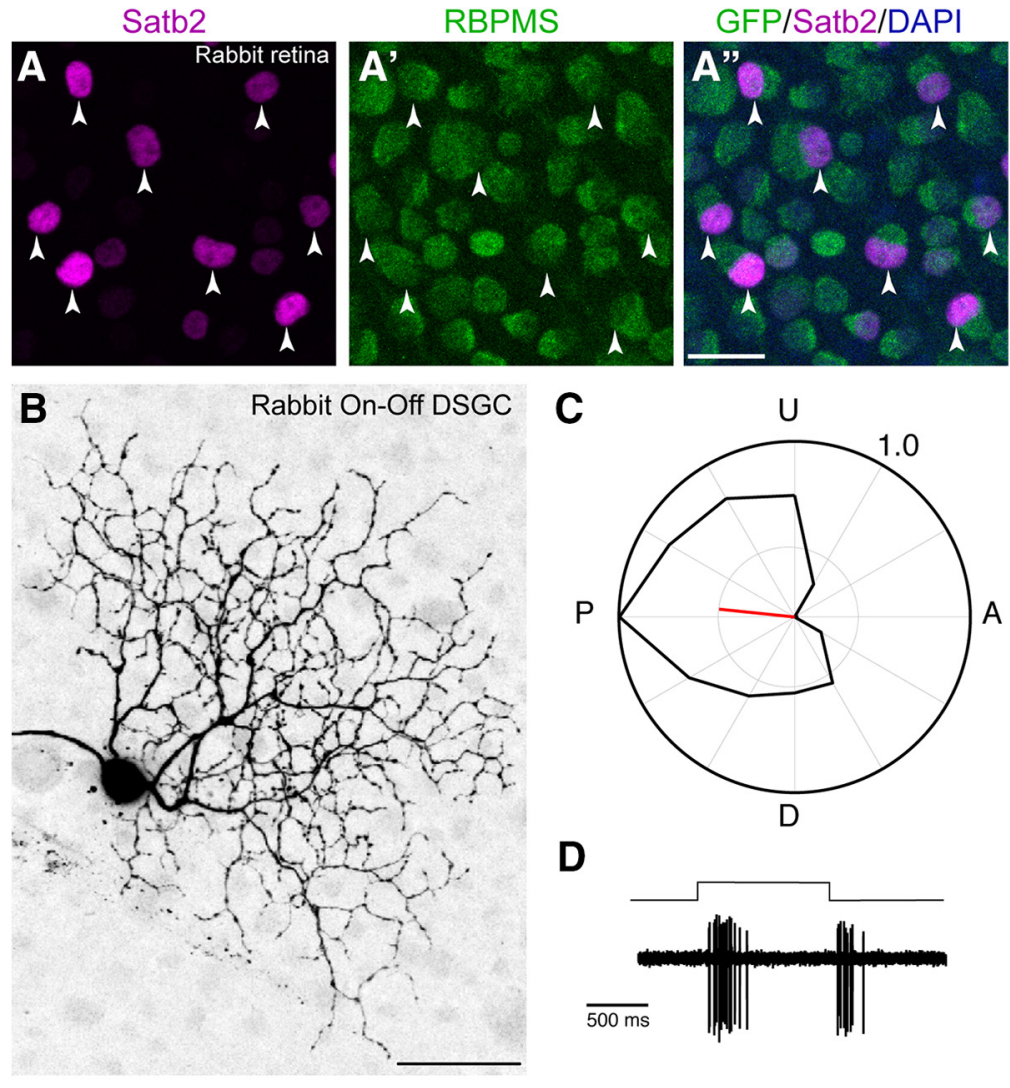

C

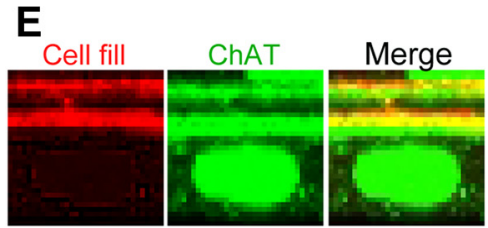

$\mathbf{F}$
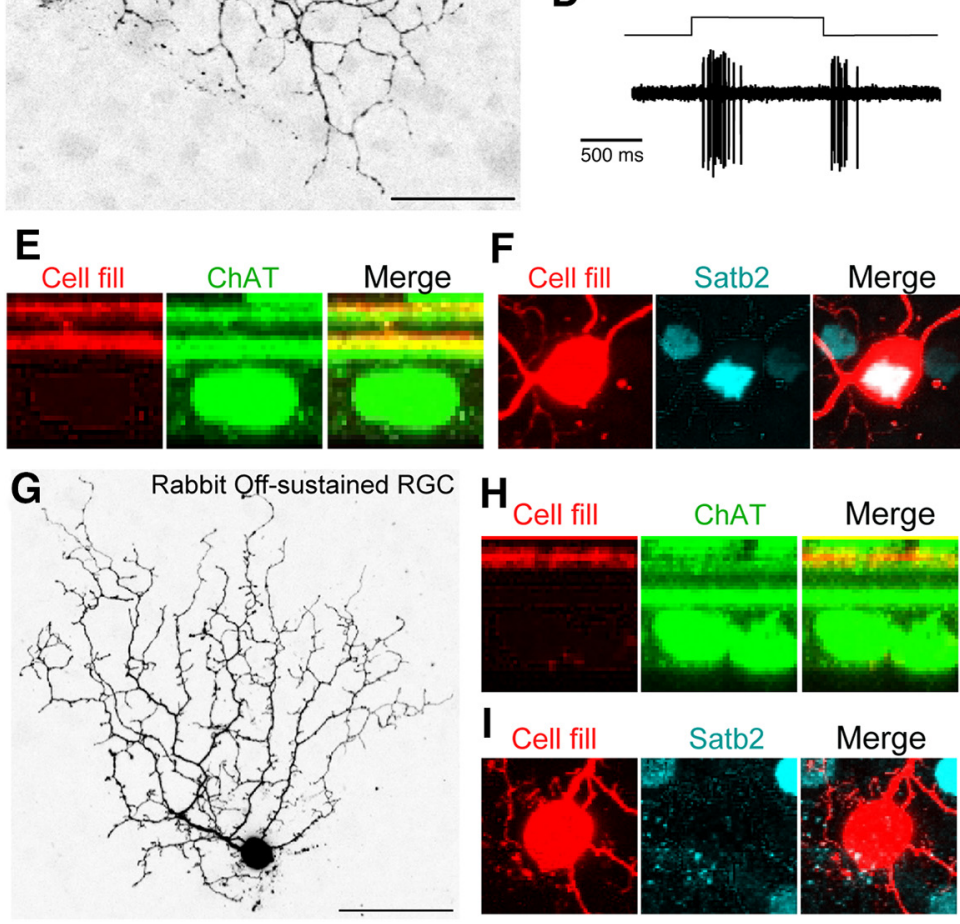

Figure 3. Satb2 expression is conserved in rabbit 0n-0ff DSGCs. $\boldsymbol{A}-\boldsymbol{A}^{\prime \prime}$, Colocalization of Satb2 (magenta, $\boldsymbol{A}$ ) with RBPMS marker (green, $\boldsymbol{A}^{\prime}$ ) in the rabbit retina. $\boldsymbol{B}$, En face view of a dye-filled posterior-tuned On-Off DSGC. $\boldsymbol{C}, \boldsymbol{D}$, Cell in $\boldsymbol{B}$ was identified physiologically based on directional tuning to drifting gratings $(\boldsymbol{C}$ and based on 0 n-0ff light responses $(\boldsymbol{D})$. $\boldsymbol{E}$, Dendrites of the filled cell (red) co-stratify with starburstamacrine cell dendrites (ChAT, green). $\boldsymbol{F}$, Recorded posterior-tuned rabbit DSGC (red) expressed Satb2 (cyan). G-I, Example of a recorded, dye-filled and Satb2 stained Off-sustained RGC. This non-DSGC does not express Satb2 (I). A, Anterior; P, posterior; U, upward; D, downward; ChAT, choline acetyltransferase. Scale bars, $25 \mu \mathrm{m}\left(\boldsymbol{A}^{\prime \prime}\right), 50 \mu \mathrm{m}(\boldsymbol{B}, \boldsymbol{G})$.

from Liao et al., 2016; Fig. $4 F$ ). Together, these data suggest that Satb 2 may be expressed by a single RGC type.

\section{Rabies virus circuit mapping in primate implicates} Satb2-RGCs in image formation

The retino-geniculo-cortical pathway is the main conduit for spatial vision and the basis for visual perception. In primates, this pathway is dominated by midget and parasol RGC inputs, however, the dLGN receives visual information other RGC types as 

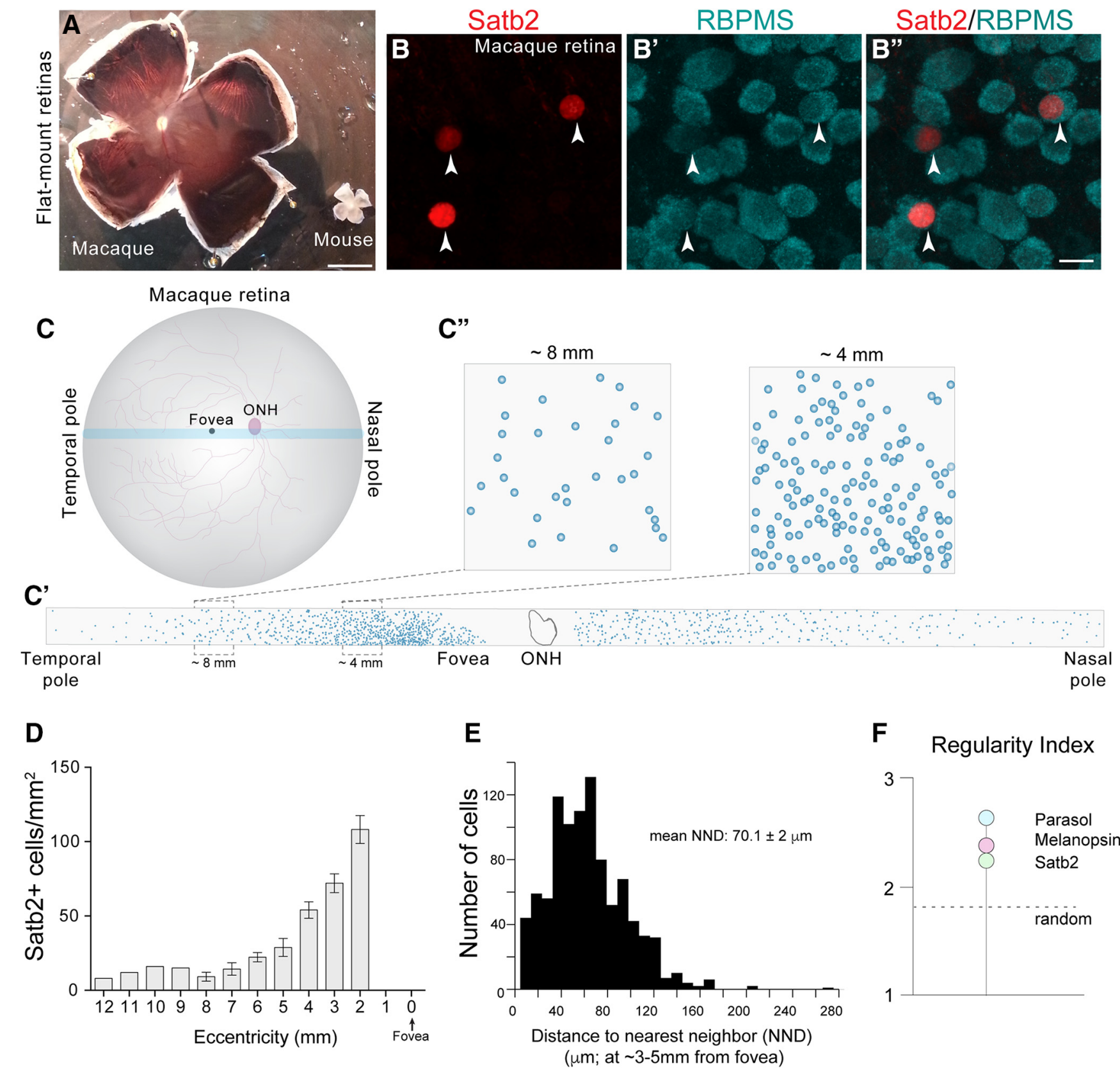

Figure 4. Satb2 is expressed by a restricted subset of macaque RGCS. $\boldsymbol{A}$, Photomicrograph of an example macaque retina (left) compared with a mouse retina (right). $\boldsymbol{B}-\boldsymbol{B}^{\prime \prime}$, Satb2 (red) expression completely overlaps with the expression of RBPMS, a RGC-specific marker (cyan), in the macaque retina. White arrowheads indicate colocalization of Satb2 and RBPMS. $C-C^{\prime \prime}$, Example density plot of Satb2-RGCs. Schematic ( $C$ ) shows area of Satb2-immunostained-retina imaged (blue) relative to major retinal landmarks [fovea: black circle; optic nerve head (ONH): pink circle]. Satb2-RGC (blue dots) locations plotted within a $1 \mathrm{~mm}$ wide strip along the temporal-nasal axis $\left(\boldsymbol{C}^{\prime}\right)$. Insets show Satb2-RGCs (blue dots) within the peripheral $(\sim 8 \mathrm{~mm})$ to central $(\sim 4 \mathrm{~mm})$ retina $\left(\boldsymbol{C}^{\prime}\right)$. $\boldsymbol{D}$, Quantification of Satb2-RGC density as a function of retinal eccentricity. $\boldsymbol{E}$, Distribution of the distances between nearest-neighbor Satb2-RGCs. $\boldsymbol{F}$, Regularity index of Satb2-RGC (from this study) compared with parasol RGCs and melanopsin RGCs from Liao et al. (2016). Scale bars, $2 \mathrm{~mm}(\boldsymbol{A}) ; 10 \mu \mathrm{m}\left(\boldsymbol{B}^{\prime \prime}\right)$.

well (Dacey et al., 2003; Crook et al., 2008; Szmajda et al., 2008; Percival et al., 2014). To determine whether Satb2-RGCs contribute to the retino-geniculo-cortical pathway, we stereotaxically injected modified rabies virus (glycoprotein deleted) encoding fluorescent reporter proteins (Rb- $\Delta \mathrm{G}$-XFP; X: GFP or mCherry) into the dLGN of adult macaques in vivo. Rb- $\Delta \mathrm{G}-\mathrm{XFP}$ infects neurons via their presynaptic terminals and thus retrogradely labels RGCs that are synaptically connected to geniculate neurons (schematized in Fig. 5A, $A^{\prime}-B^{\prime \prime}$; Dhande et al., 2013; Cruz-Martín et al., 2014). Rb- $\Delta$ G-XFP does not progress beyond the initially infected neuron, but does "fill" the entire cell with fluorescent reporter expression, allowing high specificity and resolution vi- sualization of dLGN-projecting RGCs. By combining this approach with harvesting and immunostaining of the entire retina for Satb2, we discovered that at least some of the Satb2-expressing RGCs in the macaque retina extend axons to the brain, which synapse in the dLGN (Fig. $5 B-B^{\prime \prime}$ ). The retinal distribution pattern of Satb2-RGCs (see above) together with their projections to the dLGN suggest that Satb2-RGCs may play a role in supporting cortically based visual processing.

Because Rb- $\Delta \mathrm{G}$-XFP infection results in complete fluorescent labeling of the soma, axons, and dendrites of the infected RGCs, we were able to characterize the infected cells' morphologies and compare them with other known primate RGC types (Fig. 5C-E), 

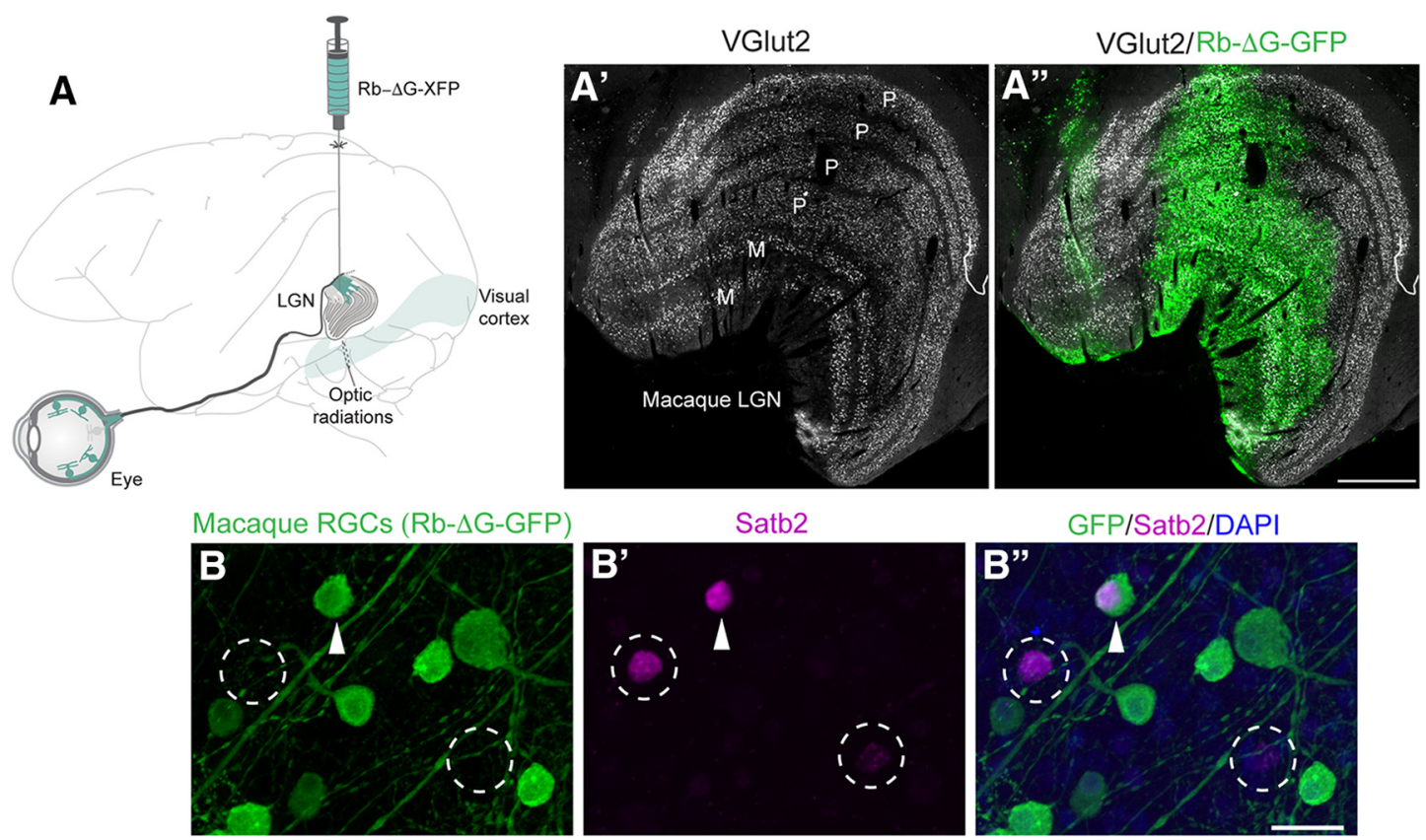

Satb2

GFP/Satb2/DAPI
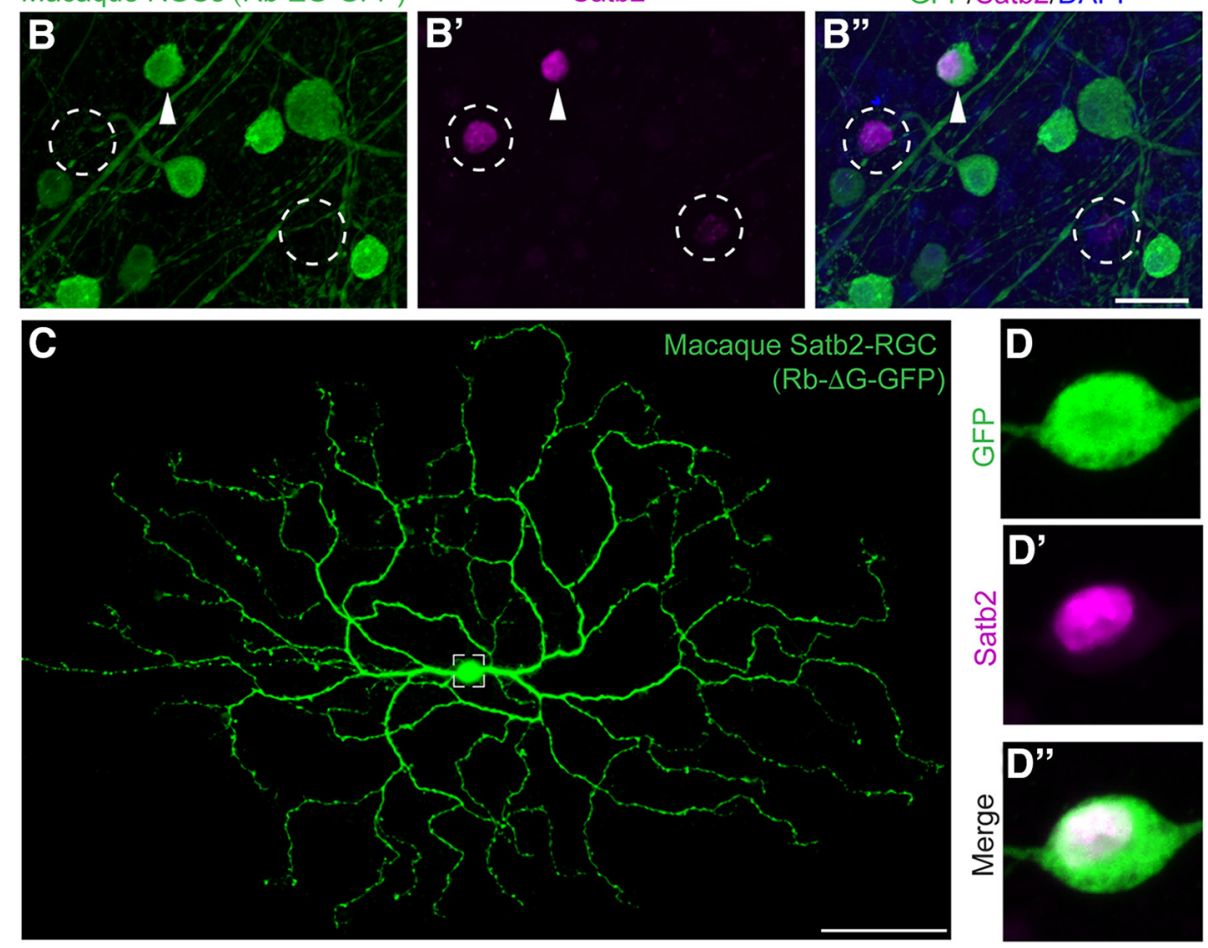

$\mathbf{E}$

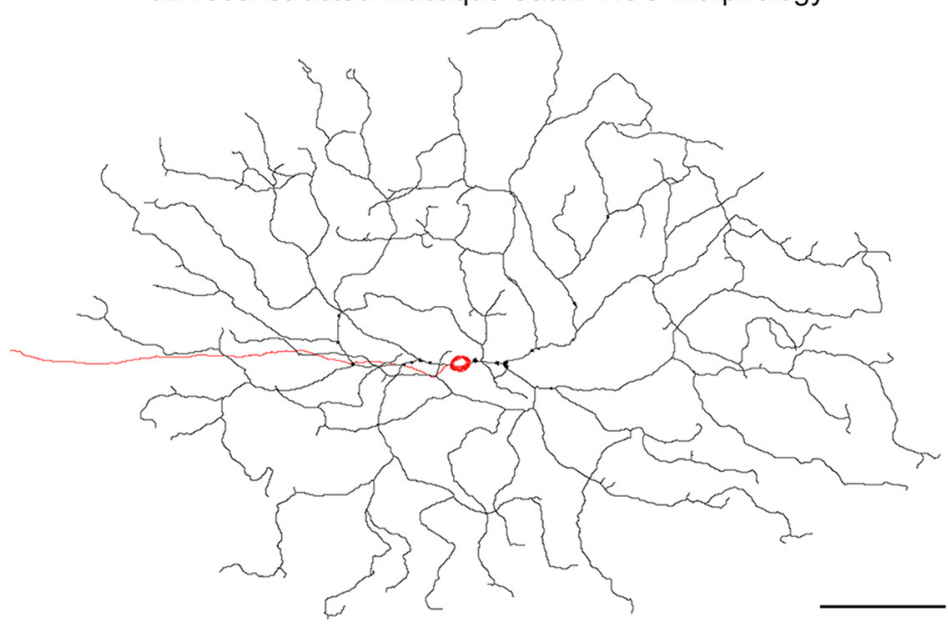

Figure 5. Macaque Satb2-RGCs are synaptically connected to geniculate neurons. $A$, Schematic demonstrating injection of $\mathrm{G}$-deleted rabies virus (Rb- $\Delta \mathrm{G}$ ) encoding fluorescent proteins in the dLGN. $\boldsymbol{A}^{\prime}, \boldsymbol{A}^{\prime \prime}$, Local infection/spread of Rb- $\Delta$ G-GFP (green) within the dLGN ( $\left.\boldsymbol{A}^{\prime \prime}\right)$. dLGN layers visualized by VGlut2 staining $\left(\boldsymbol{A}^{\prime}\right.$, white). $\boldsymbol{B}-\boldsymbol{B}^{\prime \prime}$, Injection of Rb- $\Delta \mathrm{G}-\mathrm{GFP}$ in dLGN results in infection of RGCS $(\boldsymbol{B})$ that form synapses with geniculate neurons. Satb2 (magenta, $\boldsymbol{B}^{\prime}$ ) is expressed by some dLGN projecting RGCs (green, $\boldsymbol{B}$ ). White arrowheads indicate colocalization of GFP and Satb2 and dashed circles indicate lack thereof. $\boldsymbol{C}$, Example en face view of Satb2-RGC morphology recovered from rabies GFP infection. $\boldsymbol{D}-\boldsymbol{D}^{\prime \prime}$, Higher magnification of Satb2-RGC soma ( $\boldsymbol{D}$, green) expressing Satb2 ( $\boldsymbol{D}^{\prime}$, magenta). $\boldsymbol{E}$, 3D reconstruction of Satb2-RGC dendritic morphology (black) shown in $\boldsymbol{C}$. Soma and axon shown in red. XFP: GFP or mCherry fluorescent protein; $M$, magnocellular layer; $P$, parvocellular layer. Scale bars, $1 \mathrm{~mm}\left(\boldsymbol{A}^{\prime \prime}\right), 25 \mu \mathrm{m}\left(\boldsymbol{B}^{\prime \prime}\right), 100 \mu \mathrm{m}(\boldsymbol{C}, \boldsymbol{E})$. 


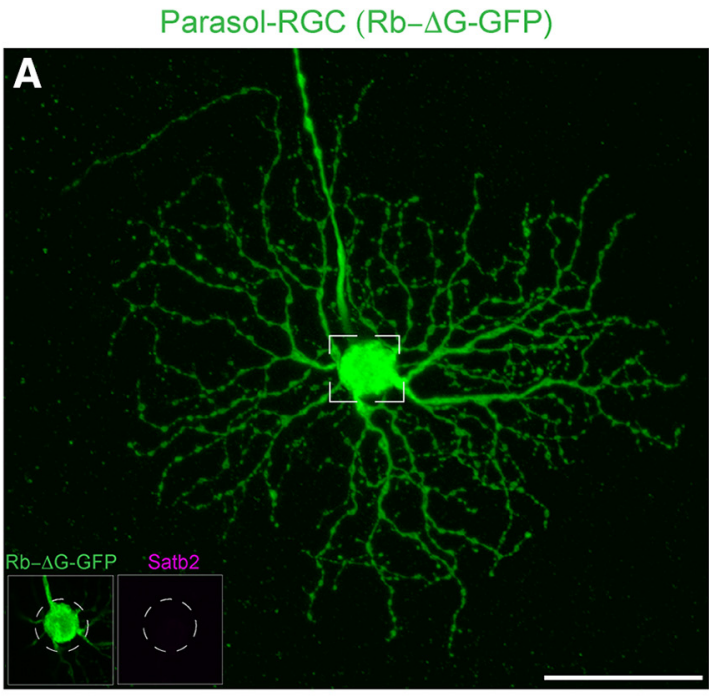

B

Midget-RGC $(\mathrm{Rb}-\triangle \mathrm{G}-\mathrm{GFP})$

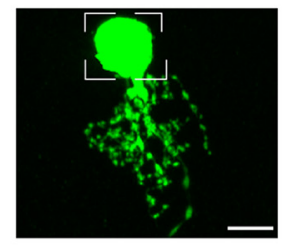

$\mathrm{Rb}-\triangle \mathrm{G}-\mathrm{GFP}$ Satb2

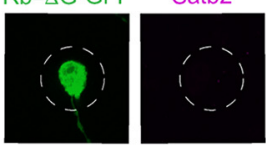

Melanopsoin- RGCs (Rb- $\Delta \mathrm{G}-\mathrm{GFP})$
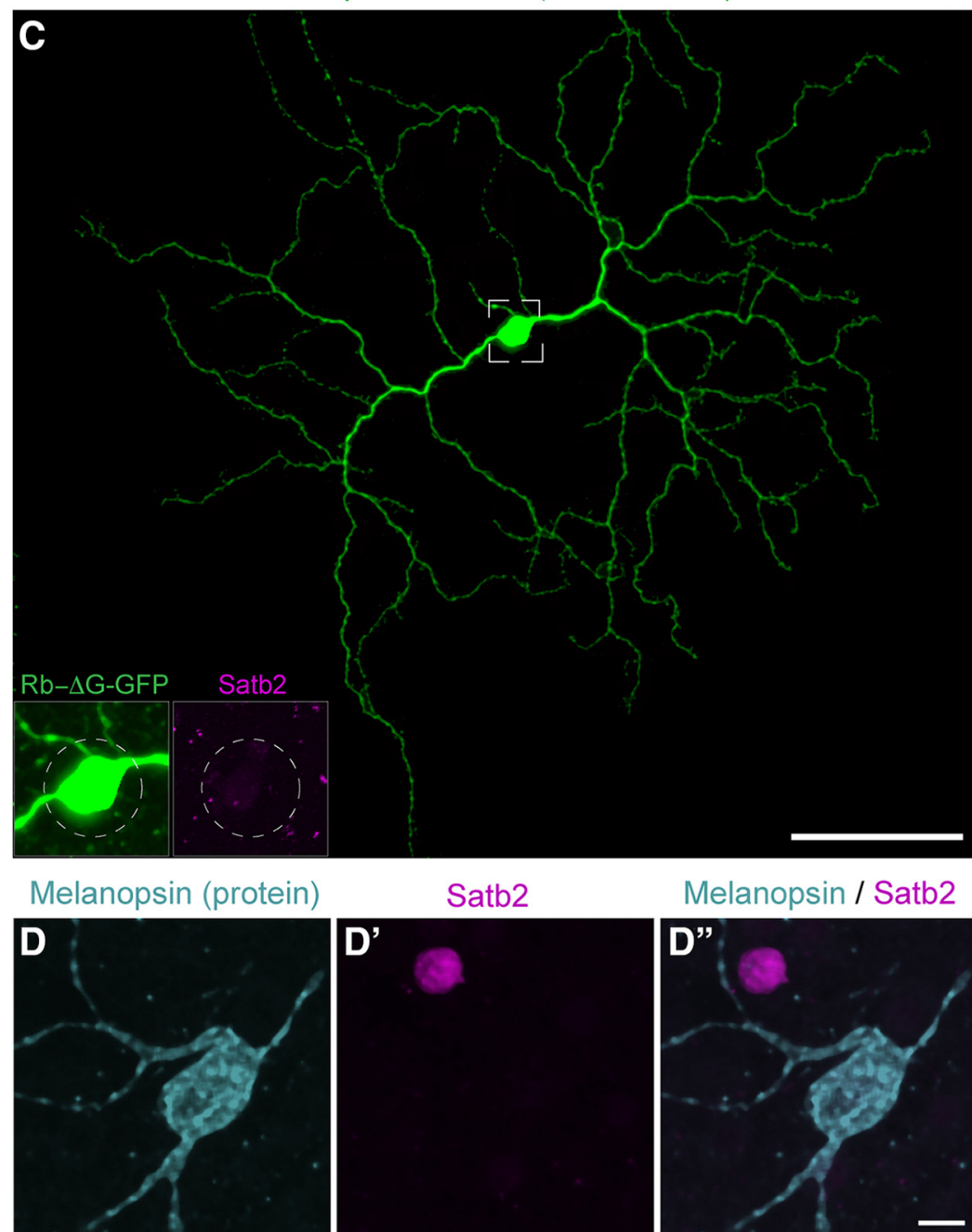

Satb2

Melanopsin / Satb2
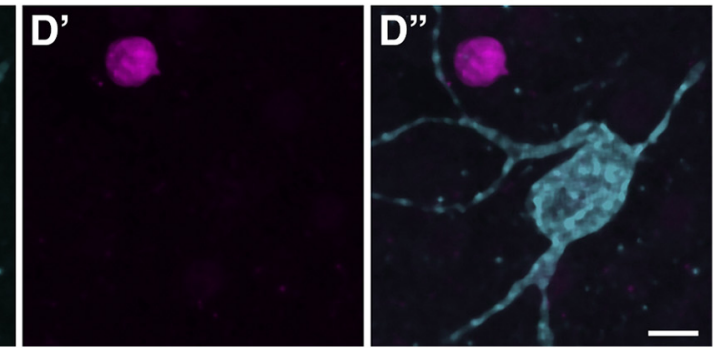

Figure 6. Parasol, midget, and melanopsin RGCs in the macaque retina do not express Satb2. $A, B$, Example en face view of On parasol RGC $(\boldsymbol{A})$ and Off midget RGC $(\boldsymbol{B})$ morphology recovered from rabies GFP infection. Insets show lack of expression of Satb2. C, Example en face view of melanopsin RGC morphology recovered from rabies GFP infection. Inset (left) shows lack of expression of Satb2. D- $\boldsymbol{D}^{\prime \prime}$, RGCs expressing melanopsin photopigment ( $\boldsymbol{B}$, cyan) do not express Satb2 ( $\boldsymbol{B}^{\prime}$, magenta). Scale bars, $100 \mu \mathrm{m}$ ( $\boldsymbol{C}$; $50 \mu \mathrm{m}(\boldsymbol{A}) ; 10 \mu \mathrm{m}\left(\boldsymbol{B}, \boldsymbol{D}^{\prime \prime}\right)$. including parasol and midget ganglion cells, which together account for $\sim 75 \%$ of all macaque RGCs (Dacey, 2004; Wässle, 2004). Parasol and midget RGCs did not express Satb2 (On- and Off-parasol RGCs expressing Satb2: 0/4; On- and Offmidget RGCs expressing Satb2: 0/7; Fig. $6 A, B)$. In addition, Rb- $\Delta \mathrm{G}$-XFP also labeled melanopsin RGCs identified by their "giant" dendritic fields and monostratified dendrites (Dacey et al., 2005) and these cells also did not express Satb2 protein $(n=4$ cells; Fig. $6 C)$. Moreover, we also stained macaque retinas with antibodies against melanopsin protein and Satb2 and found no colabeling between these two markers ( $n=37$ cells; Fig. $6 D)$, similar to our findings in mice (see above).

\section{Unique morphological features of macaque Satb2-RGCs}

Analysis of the dendritic morphology of Satb2-RGCs recovered from different retinal eccentricities (schematized in Fig. $7 A, B-D$ ) revealed several interesting morphological aspects. First, these cells have large dendritic fields; the average dendritic field of a Satb2-RGCs is significantly larger than that of midget or parasol RGCs (Figs. 5E, 7B-F; mean dendritic diameters: Satb2-RGCs: $428 \pm 40 \mu \mathrm{m}, n=10$ cells; On- and Off-parasol RGCs: $184 \pm 6$ $\mu \mathrm{m}, n=35$; On- and Off-midget RGCs: $62 \pm 3 \mu \mathrm{m}, n=10 ; p=2.4 \times 10^{-12}$ for Satb2-RGCs vs parasol RGCs and $p=$ $7.9 \times 10^{-8}$ for Satb2-RGCs vs midget RGCs). Also, Satb2-RGCs tended to have smaller dendritic fields than melanopsin RGCs, which are the largest RGCs identified thus far in the macaque retina (mean dendritic diameter of macaque melanopsin RGC: $566 \pm 118 \mu \mathrm{m}, n=3 ; p=0.17$; Liao et al., 2016: 718-761 $\mu \mathrm{m})$. Second, the dendritic branching of Satb2-RGCs was relatively sparse, especially in comparison to midget and parasol RGCs (cf. Figs. $5 E$ and $7 B-D$ vs $7 E$ ). Satb2-RGCs had significantly fewer branch points in comparison to parasol RGCs (mean number of dendritic branches: Satb2-RGCs: $116 \pm$ 25, $n=8$; On- and Off-parasol RGCs: $212 \pm 24, n=5 ; p=0.03$; Fig. $7 G$, inset). To further quantify dendritic complexity, we performed Sholl analysis (see the Materials and Methods), which revealed that Satb2-RGCs make significantly fewer dendritic intersections in comparison to parasol RGCs (Satb2-RGCs: $n=10$; parasol RGCs: $n=5$; Ring1-10: $p=0.6969$, $p=0.0163, p=0.0004, p=0.0001, p=$ $0.0024, p=0.0161, p=0.0061, p=0.1086$, $p=0.6572, p=0.8547$; Fig. $7 G)$. Together, 

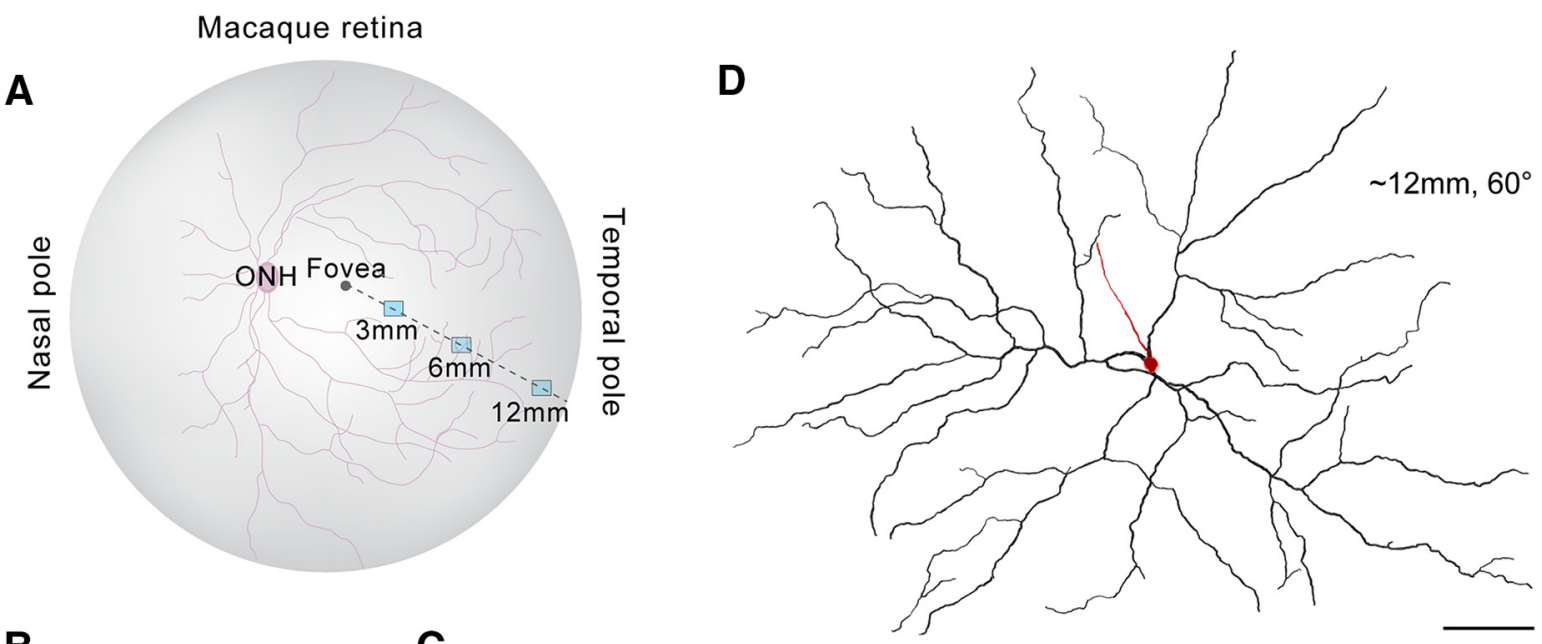

B

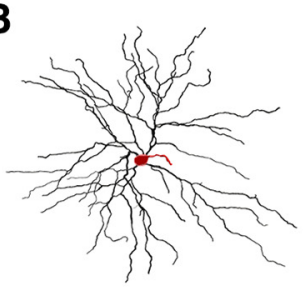

$\sim 3 \mathrm{~mm}$ from fovea, $10^{\circ}$
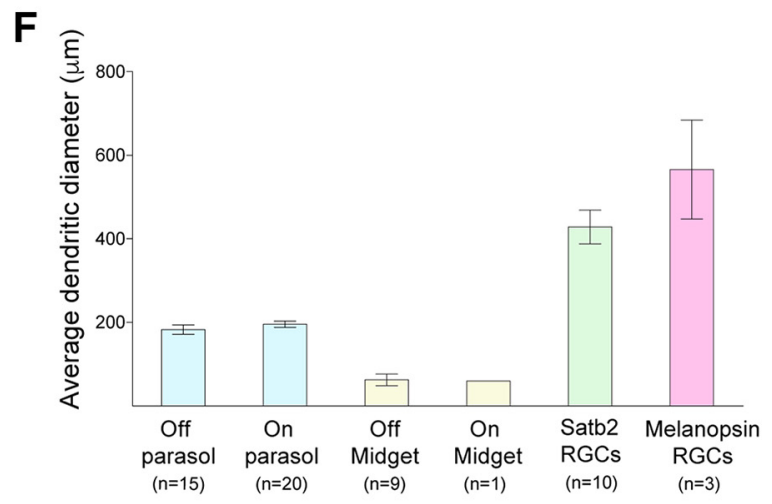

H

INL

$=-$

$\overline{G C L}$

\section{I}
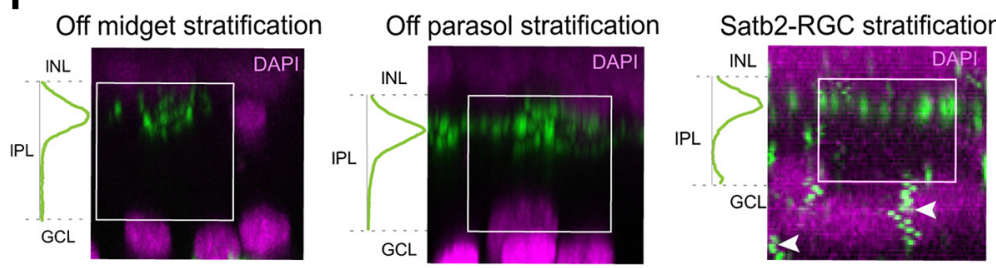

C

E
Midget-RGC

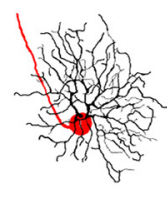

G

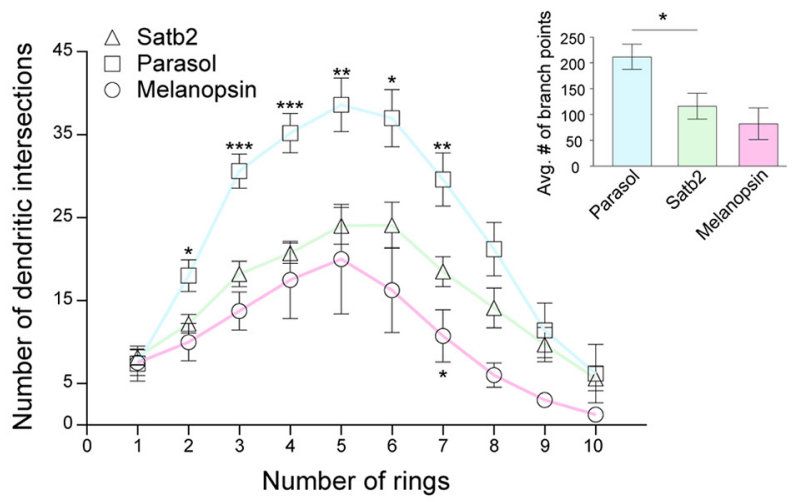

J

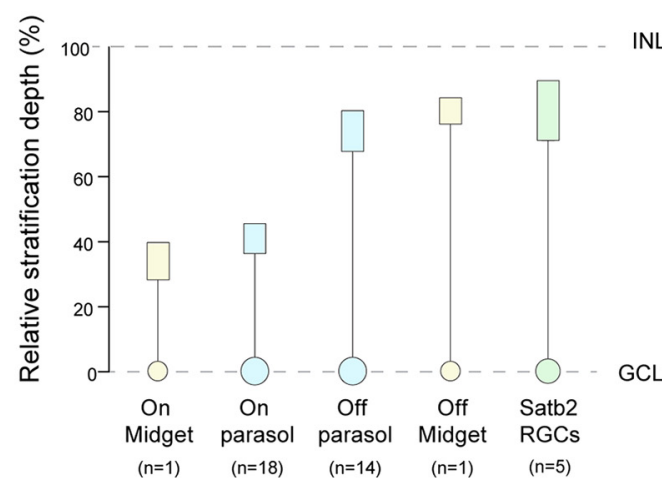

Figure 7. Macaque Satb2-RGCs are morphologically divergent from mouse 0n-OffDSGCS. $\boldsymbol{A}-\boldsymbol{D}$, Example en face reconstructions of Satb2-RGC dendrites recovered from rabies GFP infection from three different retinal eccentricities [(central ( $\boldsymbol{B})$, midperipheral $(\boldsymbol{C})$, and peripheral (D)]. $\boldsymbol{B}-\boldsymbol{D}$, Location of Satb2-RGCs schematized in $\boldsymbol{A}$. $\boldsymbol{E}$, Example en face reconstruction of dendrites of parasol (left) and midget (right) RGCS.F, Quantification of the dendritic diameter of Satb2-RGCS. G, Quantification of dendritic complexity as measured by Sholl analysis and the average number of branch points (inset). $\boldsymbol{H}$, Side view of dendrites of Satb2-RGC shown in D demonstrating that the dendrites of Satb2-RGCs stratify close to the inner nuclear layer. $\boldsymbol{I}$, Examples of z-projection of Off parasol, Off midget, and Satb2-RGC dendrites recovered from rabies XFP infection (green) within the inner plexiform layer (IPL). The intensity profile (green line) of the dendrite (plotted to the left) throughout the IPL is shown. Nonspecific background fluorescent signal in the tissue is marked by a white arrows. J, Quantification of Satb2-RGC dendritic stratification depth within the inner plexiform layer. ONH, Optic nerve head; INL, inner nuclear layer; GCL, ganglion cell layer. Scale bar, $100 \mu \mathrm{m}$ (D). ${ }^{*} p<0.05 ;{ }^{* *} p<0.01$; ${ }^{* * *} p<0.001$ Student's $t$ test. Figure 7-1 (available at https://doi.org/10.1523/JNEUROSCI.1784-18.2018.f7-1) demonstrates exemplars of the maximum intensity projection and corresponding reconstruction of Satb2-RGCS. 
these data demonstrate that dendritic field of Satb2 RGC is indeed larger and less complex than parasol RGCs. The complexity of Satb2-RGCs was not significantly different from melanopsin RGCs ( $n=4$; mean number of dendritic branches: $82 \pm 31, p=$ 0.43; Ring1-10: $p=0.711, p=0.355, p=0.14, p=0.368, p=$ $0.467, p=0.176, p=0.046, p=0.066, p=0.07, p=0.095$; Figure $7 G)$. Third, the dendritic area of Satb2-RGCs scales as a function of eccentricity; the arbors are smaller for cells positioned near the fovea $(\sim 220 \mu \mathrm{m}$, Fig. $7 B)$ and more than double in size $(\sim 560$ $\mu \mathrm{m}$, Fig. $7 D$ ) for the Satb2-RGCs located in the periphery. Therefore, the size of Satb2-RGCs scales inversely with their density, similar to other RGC types (Dacey, 2004; Field and Chichilnisky, 2007), thereby allowing them to maintain optimal coverage across the retina.

The vertical depth where a RGC's dendrites stratify within the inner plexiform layer of the retina reflects its potential synaptic partners and thus is suggestive of its functional attributes (Roska and Werblin, 2001; Sümbül et al., 2014). Indeed, a signature feature of On-Off DSGCs in mice and rabbits is their bistratified dendritic arbor and dendritic co-stratification with the processes of SACs (Figs. 2, 3; Famiglietti, 1992; Vaney and Pow, 2000; Vaney et al., 2012). Therefore, we analyzed the stratification of macaque Satb2-RGCs (see Materials and Methods) and found that the dendrites of all macaque Satb2-RGCs were monostratified (Fig. $7 \mathrm{H}-J$ ). Their dendrites stratified distal from their cell bodies and close to the inner nuclear layer (Fig. $7 \mathrm{I}, \mathrm{J}$; relative depth: $79 \pm 3 \%, n=5$ ), similar to the stratification depth of Off-parasol and Off-midget RGCs (Fig. 7 I,J; relative depth: $75 \pm$ $2 \%, n=14$ and $76 \pm 2 \%, n=1$, respectively).

Collectively, these data demonstrate that Satb2-RGCs in the macaque retina are strikingly different from Satb2-expressing On-Off DSGCs found in mice and rabbits. The monostratification of their large arbors in the Off sublamina of the inner plexiform layer suggest they respond to light offsets (Off RGCs). Multiple types of monostratified large-field RGCs have been previously identified in the macaque retina (Dacey, 2004; Yamada et al., 2005). The stratification depth and branching pattern of Satb2-RGCs most closely resemble the morphology of the outer-sparse-monostratified RGCs described by Dacey (2004). However, a direct comparison is difficult because quantitative descriptions of the morphological properties of outer-sparsemonostratified RGCs are lacking. Regardless, our data indicate that, even though Satb2 is expressed by mouse, rabbit, and macaque RGCs, the type of RGCs expressing Satb2 in macaque seems markedly different.

\section{Imaging visual responses of mouse Satb2-RGCs uncovers their diversity}

One possible explanation for our results is that Satb2 was repurposed in primate evolution and now marks one or more RGC type(s) that are different from Satb2-RGCs in mice and rabbits. Alternatively, the fact that Satb2-RGCs in primate are morphologically distinct from their mouse and rabbit "counterparts" may point to a different possibility: that there is a conserved monostratified Off RGC type in all three studied species that we overlooked. Indeed, our electrophysiological analysis of mouse and rabbit retina was not exhaustive and was focused on targeting On-Off DSGCs. Therefore, to determine whether there is a conserved Satb2 RGC in all three species, we decided to reexamine Satb2-expressing RGC types in the mouse retina using a more systematic, unbiased approach. We imaged light-evoked calcium signals across large populations of RGCs and used a battery of visual stimuli (e.g., full-field chirp, moving bars, dense noise) shown previously to discriminate a broad range of RGC types based on their functional properties (Fig. 8; Baden et al., 2016). After the recordings, we stained the imaged retinas for Satb2 and the RGC marker RBPMS to identify the Satb2-RGCs from among the recorded RGC population (Fig. $8 B, C$ ).

Using this approach, we recorded visual responses from 1290 cells ( $n=4$ retinas/mice). Of these cells, 58 cells expressed Satb2, with 42 Satb2-positive cells passing the quality criterion (Baden et al., 2016). We assigned these cells to the functional clusters obtained in Baden et al. (2016). More than 70\% of the Satb2expressing cells that passed the quantity criteria were consistently allocated to three RGC groups (Fig. $8 D$ ). As expected, one major group was On-Off DSGCs (Fig. $8 D ; n=6$ cells; $\mathrm{G}_{12}$ : Baden et al., 2016) and of those On-Off DSGCs, 4/6 preferred motion along the posterior axis (Fig. $8 E$ ). These data complement the findings from our molecular and electrophysiological analysis (Figs. 1, 2) showing that, in mouse On-Off DSGC types, Satb2 is enriched in those tuned for posterior motion.

The second major group comprised a newly identified type of Off DSGCs ( $n=8$ cells; $\mathrm{G}_{2}$ : Baden et al., 2016; Fig. $\left.8 D, F\right)$. This Off DSGC type has a relatively small receptive field, stratifies between the On and Off starburst dendritic plexus, and responds to light offsets (Baden et al., 2016). The morphology, receptive field properties, and directional preference of these Satb2expressing Off-DSGCs were reported to be distinct from the Off DSGCs labeled in the JAM-B mouse line (Kim et al., 2008; Baden et al., 2016). The third major Satb2-expressing group consisted of Off-sustained RGCs that were not direction selective ( $n=7$ cells; $\mathrm{G}_{7}$ : Baden et al., 2016; Fig. 8D,F). Their dendrites stratify close to the Off starburst dendritic plexus and they respond robustly to light offset (Baden et al., 2016). The remaining 21 recorded Satb2-RGCs were distributed across 10 functional groups $\left(G_{1,4,5,7,9,11,12,14,16,17,26,29}\right.$; Fig. $\left.8 D\right)$ with similar functional properties (Off responsive or direction selective; Baden et al., 2016), possibly repressing inaccurate assignment in the clustering procedure.

Although these data demonstrate that Satb2-RGCs include RGC types other than On-Off DSGCs, it is interesting that the other two major Satb2-RGC types (Off DSGCs and Off-sustained RGCs) respond to the offset of light and stratify their dendrites in the Off sublamina of the inner plexiform layer, similar to the stratification depth of macaque Satb2-RGCs. Therefore, if OnOff DSGCs are present in the primate retina, then they do not appear to express Satb2. At the same time, our results indicate that some Satb2-RGC groups might be conserved between mice and macaque monkeys.

\section{Discussion}

Visual motion detection is a behaviorally relevant and evolutionarily conserved computation. Decades of work has focused on the cells, circuits, and mechanisms that underlie motion detection, in particular directional motion detection, in the visual system of various species, including primates. Whether DSGCs are present in the primate retina essentially remains mysterious. One major hindrance to solving this problem has been that anatomical and physiological approaches alone do not allow unequivocal identification of common cell types across species. Although the addition of molecular markers does not resolve it entirely, it can bolster the effort. Indeed, here we show that, by identifying the transcription factor Satb2 as a new molecular marker of rabbit and mouse On-OffDSGCs and a subset of mouse OffDSGCs and mouse Off-sustained RGCs, we were able to probe the relationship between Satb2-RGCs across these species and in the primate 
A

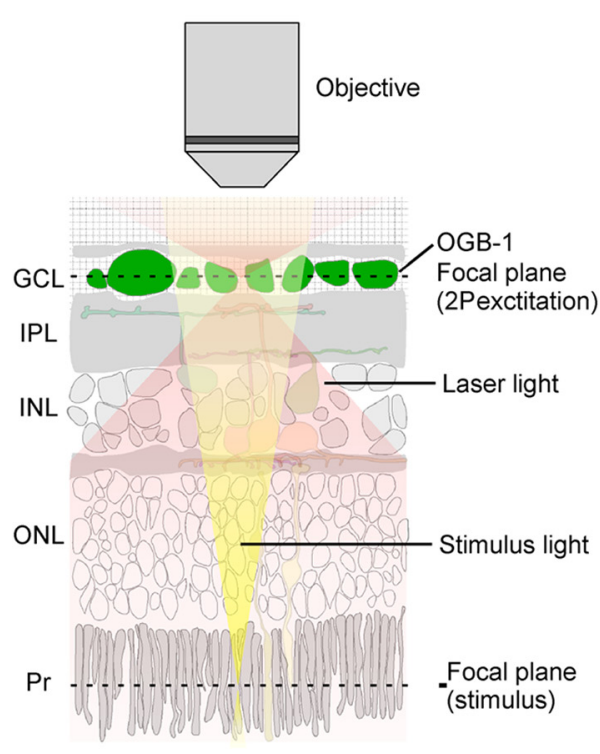

B

OGB-1 SR-101

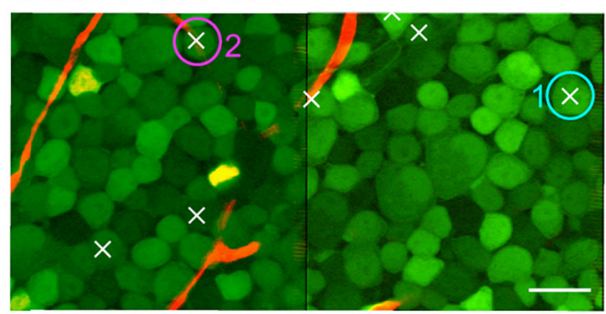

C

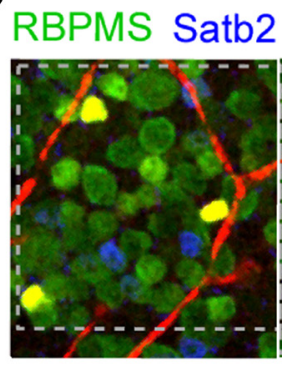

D

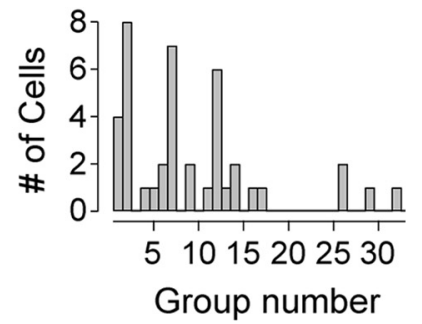

Group 12 : On-Off DSGCs

$\mathbf{E}_{1} \quad$ Full-field chirp Moving bar

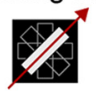

$A \overbrace{U}^{D} P$

Dense noise

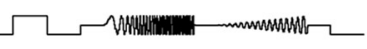

1

$\mathrm{E}_{2}$

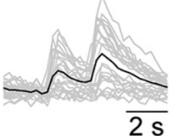

$M \mu$
$m M$<smiles>C=CC=CCC</smiles>

$-4=$

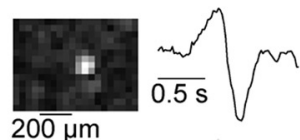

$F_{1}$

Group 2 : Off DSGCs
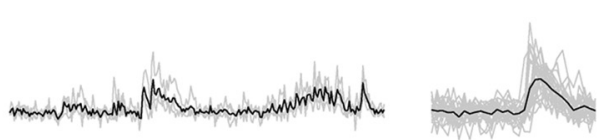
at wh
wh the wh Now wh
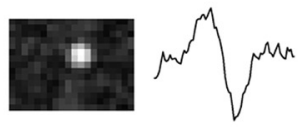

$F_{2}$

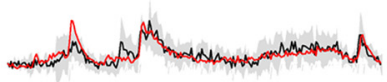<smiles>C1CC1</smiles><smiles>CC(C)(I)C(C)(C)I</smiles><smiles>CCCC</smiles>

\section{Group 7 : Off-sustained RGCs}

$\mathrm{G}_{1}$

(2)

$\mathrm{G}_{2}$

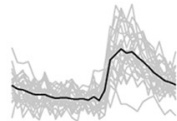

$$
\text { nh }
$$

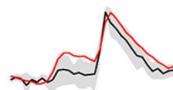

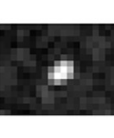
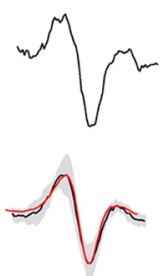

Figure 8. Mouse Satb2-RGCs comprise three functionally distinct RGC types. A, Schematic of imaging setup for recording light-evoked calcium signals form RGCs. $\boldsymbol{B}$, En face view of ganglion cell layer cells labeled with the synthetic calcium indicator Oregon Green BAPTA-1 (green) after bulk electroporation and blood vessels visualized with sulforhodamine-101 (red). White crosses indicate Satb2-expressing RGCs shown in $\boldsymbol{C}$. Responses of cells highlighted with blue and magenta circles are shown in D1 and $\boldsymbol{F 1}$, respectively. C Experimental retinal tissue in $\boldsymbol{B}$ post hoc immunostained for RBPMS (green) and Satb2 (blue), with blood vessels in red. Dotted rectangles outline the two scan fields shown in B. D, Functional clustering of Satb2-RGCs. The (Figure legend continues.) 
retina. In doing so, we revealed similarities and discovered unexpected differences between genetically "homologous" RGC types.

\section{Conserved aspects of DSGCs at the anatomical and circuit level: mice and rabbits}

Although mice and rabbits as a species diverged $\sim 80$ million years ago, in both species, there are specific types of RGCs that encode for motion along the horizontal and vertical visual axes. DSGCs in both species have a similar dendritic morphology and stratify in similar depths within the inner plexiform layer. In addition, the connectivity of On-Off DSGC dendrites with other retinal cell types (amacrine and bipolar cells) is similar between mice and rabbits (for review, see Borst and Euler, 2011; Vaney et al., 2012; Mauss et al., 2017). Moreover, whereas there are species-specific adaptations such as differences in eye size (Ding et al., 2016), many aspects of the mechanisms that underlie the computation of direction-selective signals are similar between mice and rabbits (for review, see: Borst and Euler, 2011; Vaney et al., 2012; Mauss et al., 2017; Wei, 2018). Additionally, similar to mice (Métin et al., 1988; Niell and Stryker, 2008; Marshel et al., 2012; Piscopo et al., 2013; Cruz-Martín et al., 2014), neurons selective for directional motion have been reported in the rabbit dLGN and cortex (Levick et al., 1969; Chow et al., 1971; Stewart et al., 1971; Swadlow and Weyand, 1985). The data presented here show that the similarities between mouse and rabbit DSGCs also extend to molecular markers, with both mouse and rabbit OnOff DSGCs expressing the transcription factor Satb2. Therefore, together with previous studies, there is strong evidence that the circuitry for implementing direction selectivity in the mouse and rabbit visual system evolved from a common ancestral plan.

\section{Species-specific circuit design for early stages of visual processing}

Although macaque monkeys diverged from mice and rabbits $\sim 95$ million years ago, many of the circuit elements that together form direction-selective retinal circuits in mice and rabbits are also present in the macaque retina. SACs, a type of cholinergic retinal interneuron, are critical for generating direction-selective responses in DSGCs in both mice and rabbits (Yoshida et al., 2001; Amthor et al., 2002; Euler et al., 2002; Taylor and Smith, 2012; Hillier et al., 2017) and also exist in the nonhuman primate retina (macaque and marmoset), as well as in the human retina (Hutchins and Hollyfield, 1987; Rodieck, 1989; Rodieck and Marshak, 1992; Moritoh et al., 2013; Zhang et al., 2018). Morphological surveys of RGC type variation in macaques and marmosets have proposed putative primate DSGCs based on their co-stratification with the dendrites of SACs in the inner plexi-

\footnotetext{
$\leftarrow$

(Figure legend continued.) majority of Satb2-positive cells were allocated to three functional RGC groups (Baden et al., 2016): On-Off DS (Group 12), Off DS (Group 2), and Off sustained (Group 7). E1, Calcium responses of Satb2-expressing 0n-OffDSGCs highlighted (blue circle) in $B$ in response to three different light stimuli: full-field chirp, bright bars moving in eight directions (including traces sorted by motion direction and polar plot with vector sum in red), and binary noise for space-time kernels. Single trials are shown in gray, averages in black. E2, Average calcium responses of Satb2 expressing On-Off DSGCS, with SD shading in gray and group average from Baden et al. (2016) in red. The retinocentric polar plot shows the distribution of preferred motion directions of Satb2-RGCs (black) assigned to the On-Off DSGC group (Group 12). The preferred motion directions of cells that were not Satb2 expressing are shown in gray. $\boldsymbol{F}, \boldsymbol{G}$, Calcium responses of Satb2-expressing $\operatorname{Off} \operatorname{DSGCS}(\boldsymbol{F 1}, \boldsymbol{F} 2)$ and Satb2-expressing Off-sustained RGCS $(\mathbf{G 1}, \mathbf{G 2})$. The preferred motion directions of cells that were not Satb2expressing are shown in gray $(\boldsymbol{F} 2)$. Scale bars, $20 \mu \mathrm{m}(\boldsymbol{A}, \boldsymbol{B})$.
}

form layer; Dacey, 2004; Yamada et al., 2005; Moritoh et al., 2013; Masri et al., 2016).

These observations gave rise to the expectation that On-Off DSGCs should exist in the primate retina as well. However, RGCs connected to SACs are not necessarily direction selective (Beier et al., 2013) and physiological data showing directional responses of primate RGC types resembling mouse or rabbit On-Off DSGCs are still lacking. On the contrary, there is mounting evidence that, even when cell types are conserved across species, adaptions to those cell types exist that are species specific and bestow them with visual response properties that are specific to that species. For example, although SACs are molecularly, structurally, and functionally conserved between mice and rabbits and contribute to direction selectively in both species, there are species-specific differences at the synaptic level. Ding et al. (2016) found that the synaptic distribution of excitation (from bipolar cells) and inhibition (from neighboring SACs) is different between mouse and rabbit SACs. Moreover, using a computational model based on these connectivity patterns, they revealed that the difference in input/output organization along the SAC dendrites between mice and rabbits likely enables the mouse retina to detect slower velocities than the rabbit retina (Ding et al., 2016).

Interestingly, there are also human- and macaque-specific adaptions in the distribution of SACs in the retina. In the adult human and macaque retina, there are dramatically fewer Offsublamina-stratifying SACs than there are On-sublaminastratifying SACs (Rodieck and Marshak, 1992; Yamada et al., 2005; Zhang et al., 2018). This is in stark contrast to the distribution of On and Off SACs in mice, which have a similar molecular signature to primate SACs (Zhang et al., 2018) but are found in relatively equal numbers. Importantly, the sparsity of Off SACs in humans and macaques can be extended to imply that, if On-Off DSGCs existed in these species, then the circuit underlying direction selectivity to negative contrast (the Off response component) is unlikely to rely on asymmetrical inhibition from Off-SACs, as has been reported in both mice and rabbits (Borst and Euler, 2011; Taylor and Smith, 2012; Vaney et al., 2012; Mauss et al., 2017).

Other examples of species-specific adaptations can be found in intrinsically photosensitive RGCs (ipRGCs), which are perhaps the best conserved RGC type between mice and primates, including their molecular identity, projection pathway, and behavioral roles (for review, see Dhande et al., 2015). However, Johnson et al. (2017) recently showed in tree shrews that some ipRGCs are dopaminergic and proposed that this adaption may increase retinal sensitivity and compensate for the fewer rod photoreceptors found in that species. In addition, Dacey et al. (2003) found that ipRGCs in the macaque encode color opponency, a feature not found in morphologically homologous rodent ipRGCs. Our data further our understanding of species-specific differences in overtly similar cell types and circuits. We find that Satb2 expression is expanded in rabbits to include DSGCs that encode for directional motion along the horizontal and vertical cardinal axes, whereas in mice, Satb2 expression in DSGCs is restricted to those encoding anterior or posterior directional motion.

A recent report showed that Satb1, a homolog of Satb2, plays a central role in establishing the signature bistratified dendritic architecture of On-Off DSGCs and the investigators postulated that Satb2 may also play a role in establishing DSGC dendritic morphology (Peng et al., 2017). Whether Satb2 exerts its influence on rabbit DSGCs at a structural level as well remains to be 
determined. In the future, it will be highly worthwhile to unravel the functional role of Satb2 in both mice and rabbits.

A reasonable argument for the lack of functional evidence for DSGCs in the primate retina is the difficulty in identifying them reliably and consistently because these putative DSGC types comprise a very small fraction $(<3 \%)$ of the total RGC population. However, it cannot be excluded that On-Off DSGCs are simply lacking in the primate retina. The macaque retina appears to be organized to support high-acuity vision, with $\sim 80 \%$ of the RGCs being midget and parasol ganglion cells and the remaining $\sim 20$ other RGC types each comprising $\sim 1 \%$ of the population. This massive disparity in the proportion of RGC types, compounded with the different and arguably more complex ethological demands, may have led to some RGC types such as On-Off DSGCs being evolutionarily discarded or repurposed. Molecular analysis of primate RGCs thus far supports this view. Long et al. (2016) recently showed that CART (cocaine- and amphetamine-regulated transcript), another marker for mouse DSGCs (Kay et al., 2011), is not expressed by RGCs in the macaque (or baboon) retina. In addition, we show here that Satb2-RGCs in primates represent a single type of monostratified-RGCs, unlike mouse Satb2-RGCs, which comprise three distinct functional types including On-Off DSGCs, Off DSGCs, and Off-sustained RGCs. However, our data cannot rule out the possibility that macaque Satb2-RGCs with On-Off DSGC-like morphology do exist but express Satb2 at levels that are too low to detect by standard immunohistochemistry. This suggests that the primate and mouse visual system underwent convergent evolution to solve the problem of how to detect motion. Manookin et al. (2018) recently demonstrated that parasol RGCs in macaques are motion sensitive. Although parasol RGCs do not encode for directional motion, this finding further bolsters the view that the primate retina has evolved divergent mechanisms and RGC types for motion processing.

\section{Molecular 'fingerprinting' of parallel visual pathways}

The mouse has become a mainstay model system for studying vision (Huberman and Niell, 2011). The past decade has seen an intense focus on the cells and circuits that underlie motion processing and perception in this species. This is in part due to the availability of molecular markers and genetic tools to target and manipulate different elements of the motion-sensitive visual pathways (Dhande et al., 2015; Sanes and Masland, 2015; Seabrook et al., 2017). Our findings add to the growing list of RGCtype-specific molecular markers. We describe Satb2 as a marker for On-Off DSGCs (also recently reported by Sweeney et al., 2017). Sweeney et al. (2017) found that nearly all posteriormotion-preferring DSGCs (Trhr-GFP RGCs and Drd4-GFP RGCs) express Satb2, whereas very few upward-motionpreferring DSGCs (Hb9-GFP RGCs) express Satb2, which is consistent with our results. However, a recent study by Peng et al. (2017) reported that Satb2 is highly enriched in H9-GFP RGCs. One reason for this discrepancy could be the specific antibody for Satb2 used and its specificity (discussed in Materials and Methods). We extend those findings to reveal that, in mice, Satb2 is expressed not only by anterior- and posterior-motion-preferring DSGCs, but also by two groups of Off-responsive RGC types (Off-DS and sustained-Off).

Mouse vision is low acuity compared with nonhuman primates and humans. An overarching goal of visual neuroscience is to understand how different cell types and circuits contribute to vision in primates-in particular, macaque monkeys, which have visual systems very similar to that of humans-and in humans themselves. Therefore, although understanding the role of Satb2-RGCs in mouse vision is important, it is also critical to understand how feature detectors in primates support visual perception and behaviors. Indeed, with the exception of a few RGC types, our understanding of the functional channels relayed by the primate retina to various brain centers remains scant (for review, see Field and Chichilnisky, 2007). Cell-typespecific molecular signatures gleaned from mice represent an additional and powerful entry point into studying the structure and function of primate parallel optic pathways. Only a few studies, including this one, have used mouse markers to study RGC diversity in the primate retina and already these studies are uncovering novel and unexpected species-specific features (discussed above; Satb2-RGCs: this study; Foxp2-RGCs: Rousso et al., 2016; ipRGCs: Hannibal et al., 2004, 2017; Dacey et al., 2005; Liao et al., 2016; Johnson et al., 2017). The next major step will be to develop viral and molecular tools that allow genetic access to these cell types. For example, Fitzpatrick and colleagues were able to specifically target and study the tuning properties of GABAergic neurons in the ferret visual cortex by virally expressing the calcium indicator GCaMP driven by an evolutionarily conserved mouse-GABAergic-enhancer element (Dimidschstein et al., 2016; Wilson et al., 2017). Also likely to be powerful are newly developed in vitro preparations of human cortex and primate retina in which the tissue can be kept alive long enough to express transgenes delivered biolistically or from viral vectors that can be controlled by cell-type-specific enhancers (Fradot et al., 2011; Charbel Issa et al., 2013; Moritoh et al., 2013; Sinha et al., 2017; Ting et al., 2018). Future studies will aim at developing viral tools using conserved Satb2 regulatory elements and nanobody-based tools (Tang et al., 2013, 2015) that leverage the expression of Satb2 to drive expression of fluorescent tags, calcium indicators, or channelopsins/DREADDs, which in turn will aid in parsing the features encoded by Satb2-RGCs and, more importantly, their specific contributions to vision.

Using molecular markers and viral tools to study the organization and function of parallel visual pathways in the primate can provide unprecedented insight into visual processing and the development of more targeted methodologies for visual system regeneration and repair. Indeed, a new and exciting area of research is the production of 3D "organoids" (self-assembling miniorgans) to study human eye development and generate human models for retinal diseases (Sluch et al., 2015; Chamling et al., 2016; Kaewkhaw et al., 2016; Völkner et al., 2016; Llonch et al., 2018). Cell-type-specific markers identified in mice are being used to understand and test the diversity and fidelity of cell types in such organoids. Interestingly, Langer et al. (2018) demonstrated that RGCs generated in human retinal organoids express nearly all of the known markers for mouse On-Off DSGCs (e.g., CART). These findings clearly suggest that there is some conservation of genetic programs that create retinal neuronal diversity from mouse to humans. However, as this and other recent studies demonstrate (discussed above), extrapolating cell identify based on mouse markers is only a first step in resolving "conservation" of cell types across species. Therefore, studies such as this one fill a gap in understanding how mouse RGC markers translate to primate RGC types at the level of both dendritic morphology and projection pattern.

\section{References}

Adelson EH, Bergen JR (1985) Spatiotemporal energy models for the perception of motion. J Opt Soc Am A 2:284-299. CrossRef Medline

Agrelo R, Souabni A, Novatchkova M, Haslinger C, Leeb M, Komnenovic V, Kishimoto H, Gresh L, Kohwi-Shigematsu T, Kenner L, Wutz A (2009) 
SATB1 defines the developmental context for gene silencing by xist in lymphoma and embryonic cells. Dev Cell 16:507-516. CrossRef Medline

Alonso JM, Usrey WM, Reid RC (2001) Rules of connectivity between geniculate cells and simple cells in cat primary visual cortex. J Neurosci 21:4002-4015. CrossRef Medline

Ames A, Nesbett FB (1981) In Vitro Retina as an Experimental Model of the Central Nervous System. J Neurochem 37:867-877. Medline

Amthor FR, Oyster CW, Takahashi ES (1984) Morphology of on-off direction-selective ganglion cells in the rabbit retina. Brain Res 298:187190. CrossRef Medline

Amthor FR, Keyser KT, Dmitrieva NA (2002) Effects of the destruction of starburst-cholinergic amacrine cells by the toxin AF64A on rabbit retinal directional selectivity. Vis Neurosci 19:495-509. CrossRef Medline

Asanoma K, Kubota K, Chakraborty D, Renaud SJ, Wake N, Fukushima K, Soares MJ, Rumi MA (2012) SATB homeobox proteins regulate trophoblast stem cell renewal and differentiation. J Biol Chem 287:2257-2268. CrossRef Medline

Baden T, Berens P, Franke K, Román Rosón M, Bethge M, Euler T (2016) The functional diversity of retinal ganglion cells in the mouse. Nature 529:345-350. CrossRef Medline

Barlow HB, Hill RM (1963) Selective sensitivity to direction of movement in ganglion cells of the rabbit retina. Science 139:412-414. CrossRef Medline

Beier KT, Borghuis BG, El-Danaf RN, Huberman AD, Demb JB, Cepko CL (2013) Transsynaptic tracing with vesicular stomatitis virus reveals novel retinal circuitry. J Neurosci 33:35-51. CrossRef Medline

Bickford ME, Zhou N, Krahe TE, Govindaiah G, Guido W (2015) Retinal and tectal "driver-like" inputs converge in the shell of the mouse dorsal lateral geniculate nucleus. J Neurosci 35:10523-10534. CrossRef Medline

Bleckert A, Schwartz GW, Turner MH, Rieke F, Wong ROL (2014) Visual Space Is Represented by Nonmatching Topographies of Distinct Mouse Retinal Ganglion Cell Types. Curr Biol 24:310-315. CrossRef Medline

Borghuis BG, Marvin JS, Looger LL, Demb JB (2013) Two-Photon Imaging of Nonlinear Glutamate Release Dynamics at Bipolar Cell Synapses in the Mouse Retina. J Neurosci 33:10972-10985. CrossRef Medline

Borst A, Euler T (2011) Seeing things in motion: models, circuits, and mechanisms. Neuron 71:974-994. CrossRef Medline

Briggman KL, Euler T (2011) Bulk electroporation and population calcium imaging in the adult mammalian retina. J Neurophysiol 105:2601-2609. CrossRef Medline

Briggs F, Kiley CW, Callaway EM, Usrey WM (2016) Morphological Substrates for Parallel Streams of Corticogeniculate Feedback Originating in Both V1 and V2 of the Macaque Monkey. Neuron 90:388-399. CrossRef Medline

Chamling X, Sluch VM, Zack DJ (2016) The potential of human stem cells for the study and treatment of glaucoma. Invest Opthalmol Vis Sci 57: ORSFi1-6. CrossRef Medline

Chandra AJ, Lee SCS, Grünert U (2017) Thorny ganglion cells in marmoset retina: morphological and neurochemical characterization with antibodies against calretinin. J Comp Neurol 525:3962-3974. CrossRef Medline

Charbel Issa P, De Silva SR, Lipinski DM, Singh MS, Mouravlev A, You Q, Barnard AR, Hankins MW, During MJ, Maclaren RE (2013) Assessment of tropism and effectiveness of new primate-derived hybrid recombinant AAV serotypes in the mouse and primate retina. PLoS One 8:e60361. CrossRef Medline

Chen M, Weng S, Deng Q, Xu Z, He S (2009) Physiological properties of direction-selective ganglion cells in early postnatal and adult mouse retina. J Physiol 587:819-828. CrossRef Medline

Cheong SK, Tailby C, Solomon SG, Martin PR (2013) Cortical-like receptive fields in the lateral geniculate nucleus of marmoset monkeys. J Neurosci 33:6864-6876. CrossRef Medline

Chow KL, Masland RH, Stewart DL (1971) Receptive field characteristics of striate cortical neurons in the rabbit. Brain Res 33:337-352.

Cook JE (1996) Spatial properties of retinal mosaics: an empirical evaluation of some existing measures. Vis Neurosci 13:15-30. CrossRef Medline

Crook JD, Peterson BB, Packer OS, Robinson FR, Gamlin PD, Troy JB, Dacey DM (2008) The smooth monostratified ganglion cell: evidence for spatial diversity in the Y-cell pathway to the lateral geniculate nucleus and superior colliculus in the macaque monkey. J Neurosci 28:12654-12671. CrossRef Medline

Cruz-Martín A, El-Danaf RN, Osakada F, Sriram B, Dhande OS, Nguyen PL, Callaway EM, Ghosh A, Huberman AD (2014) A dedicated circuit links direction-selective retinal ganglion cells to the primary visual cortex. Nature 507:358-361. CrossRef Medline

Dacey D (2004) Origins of perception: retinal ganglion cell diversity and the creation of parallel visual pathways. In The Cognitive Neurosciences, (Gazzaniga MS, ed), pp. 281-301. Cambridge, MA: MIT Press.

Dacey DM, Peterson BB, Robinson FR, Gamlin PD (2003) Fireworks in the primate retina: neurotechnique LGN-projecting ganglion cell types. Neuron 37:15-27. CrossRef Medline

Dacey DM, Liao HW, Peterson BB, Robinson FR, Smith VC, Pokorny J, Yau KW, Gamlin PD (2005) Melanopsin-expressing ganglion cells in primate retina signal colour and irradiance and project to the LGN. Nature 433:749-754. CrossRef Medline

Demb JB (2007) Cellular mechanisms for direction selectivity in the retina. Neuron 55:179-186. CrossRef Medline

De Monasterio FM, Gouras P (1975) Functional properties of ganglion cells of the rhesus monkey retina. J Physiol 251:167-195. CrossRef Medline

De Valois RL, William YE, Hepler N (1982) The orientation and direction selectivity of cells in macaque visual cortex. Vision Res 22:531-544. Medline

Dhande OS, Estevez ME, Quattrochi LE, El-Danaf RN, Nguyen PL, Berson DM, Huberman AD (2013) Genetic dissection of retinal inputs to brainstem nuclei controlling image stabilization. J Neurosci 33:17797-17813. CrossRef Medline

Dhande OS, Stafford BK, Lim JA, Huberman AD (2015) Contributions of retinal ganglion cells to subcortical visual processing and behaviors. Annu Rev Vis Sci 1:291-328. CrossRef Medline

Dimidschstein J, Chen Q, Tremblay R, Rogers SL, Saldi GA, Guo L, Xu Q, Liu R, Lu C, Chu J, Grimley JS, Krostag AR, Kaykas A, Avery MC, Rashid MS, Baek M, Jacob AL, Smith GB, Wilson DE, Kosche G, et al. (2016) A viral strategy for targeting and manipulating interneurons across vertebrate species. Nat Neurosci 19:1743-1749. CrossRef Medline

Ding H, Smith RG, Poleg-Polsky A, Diamond JS, Briggman KL (2016) Species-specific wiring for direction selectivity in the mammalian retina. Nature 535:105-110. CrossRef Medline

Duan X, Qiao M, Bei F, Kim IJ, He Z, Sanes JR (2015) Subtype-specific regeneration of retinal ganglion cells following axotomy: effects of osteopontin and mTOR signaling. Neuron 85:1244-1256. CrossRef Medline

El-Danaf RN, Huberman AD (2015) Characteristic patterns of dendritic remodeling in early-stage glaucoma: evidence from genetically identified retinal ganglion cell types. J Neurosci 35:2329-2343. CrossRef Medline

El-Danaf RN, Huberman AD (2018) Sub-topographic maps for regionally enhanced analysis of visual space in the mouse retina. J Comp Neurol. Advance online publication. Retrieved April 20, 2018. doi:10.1002/ cne. 24457.

Euler T, Detwiler PB, Denk W (2002) Directionally selective calcium signals in dendrites of starburst amacrine cells. Nature 418:845-852. CrossRef Medline

Euler T, Hausselt SE, Margolis DJ, Breuninger T, Castell X, Detwiler PB, Denk W (2009) Eyecup scope: optical recordings of light stimulus-evoked fluorescence signals in the retina. Pflugers Arch 457:1393-1414. CrossRef Medline

Euler T, Haverkamp S, Schubert T, Baden T (2014) Retinal bipolar cells: elementary building blocks of vision. Nat Rev Neurosci 15:507-519. CrossRef Medline

FamigliettiEV (1992) Dendritic co-stratification of ON and ON-OFF directionally selective ganglion cells with starburst amacrine cells in rabbit retina. J Comp Neurol 324:322-335. CrossRef Medline

Field GD, Chichilnisky EJ (2007) Information processing in the primate retina: circuitry and coding. Annu Rev Neurosci 30:1-30. CrossRef Medline

FitzPatrick DR, Carr IM, McLaren L, Leek JP, Wightman P, Williamson K, Gautier P, McGill N, Hayward C, Firth H, Markham AF, Fantes JA, Bonthron DT (2003) Identification of SATB2 as the cleft palate gene on 2q32-q33. Hum Mol Genet 12:2491-2501. CrossRef Medline

Fradot M, Busskamp V, Forster VV, Cronin TT, Léveillard T, Bennett J, Sahel JA, Roska B, Picaud S (2011) Gene therapy in ophthalmology: validation on cultured retinal cells and explants from postmortem human eyes. Hum Gene Ther 22:587-593. CrossRef Medline

Hannibal J, Hindersson P, Ostergaard J, Georg B, Heegaard S, Larsen PJ, Fahrenkrug J (2004) Melanopsin is expressed in PACAP-containing retinal ganglion cells of the human retinohypothalamic tract. Invest Ophthalmol Vis Sci 45:4202-4209. CrossRef Medline 
Hannibal J, Christiansen AT, Heegaard S, Fahrenkrug J, Kiilgaard JF (2017) Melanopsin expressing human retinal ganglion cells: subtypes, distribution, and intraretinal connectivity. J Comp Neurol 525:1934-1961. CrossRef Medline

Hattar S, Liao HW, Takao M, Berson DM, Yau KW (2002) Melanopsincontaining retinal ganglion cells: architecture, projections, and intrinsic photosensitivity. Science 295:1065-1070. CrossRef Medline

Hawken MJ, Parker AJ, Lund JS (1988) Laminar organization and contrast sensitivity of direction-selective cells in the striate cortex of the old world monkey. J Neurosci 8:3541-3548. CrossRef Medline

Hillier D, Fiscella M, Drinnenberg A, Trenholm S, Rompani SB, Raics Z, Katona G, Juettner J, Hierlemann A, Rozsa B, Roska B (2017) Causal evidence for retina-dependent and -independent visual motion computations in mouse cortex. Nat Neurosci 20:960-968. CrossRef Medline

Hubel DH, Wiesel TN (1968) Receptive fields and functional architecture of monkey striate cortex. J Physiol 195:215-243. CrossRef Medline

Huberman AD, Niell CM (2011) What can mice tell us about how vision works? Trends Neurosci 34:464-473. CrossRef Medline

Huberman AD, Manu M, Koch SM, Susman MW, Lutz AB, Ullian EM, Baccus SA, Barres BA (2008) Architecture and activity-mediated refinement of axonal projections from a mosaic of genetically identified retinal ganglion cells. Neuron 59:425-438. CrossRef Medline

Huberman AD, Wei W, Elstrott J, Stafford BK, Feller MB, Barres BA (2009) Genetic identification of an on-off direction-selective retinal ganglion cell subtype reveals a layer-specific subcortical map of posterior motion. Neuron 62:327-334. CrossRef Medline

Hutchins JB, Hollyfield JG (1987) Cholinergic neurons in the human retina. Exp Eye Res 44:363-375. CrossRef Medline

Johnson EN, Westbrook T, Shayesteh R, Chen EL, Schumacher JW, Fitzpatrick D, Field GD (2017) Distribution and diversity of intrinsically photosensitive retinal ganglion cells in tree shrew. J Comp Neurol. Advance online publication. Retrieved December 14, 2017. doi:10.1002/cne.24377.

Kaewkhaw R, Swaroop M, Homma K, Nakamura J, Brooks M, Kaya KD, Chaitankar V, Michael S, Tawa G, Zou J, Rao M, Zheng W, Cogliati T, Swaroop A (2016) Treatment paradigms for retinal and macular diseases using 3-D retina cultures derived from human reporter pluripotent stem cell lines. Invest Ophthalmol Vis Sci 57:ORSFl1-ORSFl11. CrossRef Medline

Kay JN, De la Huerta I, Kim IJ, Zhang Y, Yamagata M, Chu MW, Meister M, Sanes JR (2011) Retinal ganglion cells with distinct directional preferences differ in molecular identity, structure, and central projections. J Neurosci 31:7753-7762. CrossRef Medline

Kim IJ, Zhang Y, Yamagata M, Meister M, Sanes JR (2008) Molecular identification of a retinal cell type that responds to upward motion. Nature 452:478-482. CrossRef Medline

Kirkels LAMH, Zhang W, Havenith MN, Tiesinga P, Glennon J, van Wezel RJA, Duijnhouwer J (2018) The opto-locomotor reflex as a tool to measure sensitivity to moving random dot patterns in mice. Sci Rep 8:7710. CrossRef Medline

Krahe TE, El-Danaf RN, Dilger EK, Henderson SC, Guido W (2011) Morphologically distinct classes of relay cells exhibit regional preferences in the dorsal lateral geniculate nucleus of the mouse. J Neurosci 31:1743717448. CrossRef Medline

Langer KB, Ohlemacher SK, Phillips MJ, Fligor CM, Jiang P, Gamm DM, Meyer JS (2018) Retinal ganglion cell diversity and subtype specification from human pluripotent stem cells. Stem Cell Reports 10:1282-1293. CrossRef Medline

Lee BB, Creutzfeldt OD, Elepfandt A (1979) The responses of magno- and parvocellular cells of the monkey's lateral geniculate body to moving stimuli. Exp Brain Res 35:547-557. Medline

Lee S, Zhou ZJ (2006) The synaptic mechanism of direction selectivity in distal processes of starburst amacrine cells. Neuron 51:787-799. CrossRef Medline

Lee SC, Weltzien F, Madigan MC, Martin PR, Grünert U (2016) Identification of AII amacrine, displaced amacrine, and bistratified ganglion cell types in human retina with antibodies against calretinin. J Comp Neurol 524:39-53. CrossRef Medline

Lien AD, Scanziani M (2018) Cortical direction selectivity emerges at convergence of thalamic synapses. Nature 558:80-86. CrossRef Medline

Leone DP, Srinivasan K, Chen B, Alcamo E, McConnell SK (2008) The determination of projection neuron identity in the developing cerebral cortex. Curr Opin Neurobiol 18:28-35. CrossRef Medline
Leone DP, Heavner WE, Ferenczi EA, Dobreva G, Huguenard JR, Grosschedl R, McConnell SK (2015) Satb2 regulates the differentiation of both callosal and subcerebral projection neurons in the developing cerebral cortex. Cereb Cortex 25:3406-3419. CrossRef Medline

Levick WR, Oyster CW, Takahashi E (1969) Rabbit lateral geniculate nucleus: sharpener of directional information. Science 165:712-714. CrossRef Medline

Liao HW, Ren X, Peterson BB, Marshak DW, Yau KW, Gamlin PD, Dacey DM (2016) Melanopsin-expressing ganglion cells on macaque and human retinas form two morphologically distinct populations. J Comp Neurol 524:2845-2872. CrossRef Medline

Lim JH, Stafford BK, Nguyen PL, Lien BV, Wang C, Zukor K, He Z, Huberman AD (2016) Neural activity promotes long-distance, target-specific regeneration of adult retinal axons. Nat Neurosci 19:1073-1084. CrossRef Medline

Livingstone MS (1998) Mechanisms of direction selectivity in macaque V1. Neuron 20:509-526. CrossRef Medline

Llonch S, Carido M, Ader M (2018) Organoid technology for retinal repair. Dev Biol 433:132-143. CrossRef Medline

Long Y, Bordt AS, Liu WS, Davis EP, Lee SJ, Tseng L, Chuang AZ, Whitaker CM, Massey SC, Sherman MB, Marshak DW (2016) Wide-field diffuse amacrine cells in the monkey retina contain immunoreactive Cocaineand Amphetamine-Regulated Transcript (CART). Peptides 84:22-35. CrossRef Medline

Manookin MB, Patterson SS, Linehan CM (2018) Neural mechanisms mediating motion sensitivity in parasol ganglion cells of the primate retina. Neuron 97:1327-1340.e4. CrossRef Medline

Marques T, Summers MT, Fioreze G, Fridman M, Dias RF, Feller MB, Petreanu L (2018) A role for mouse primary visual cortex in motion perception. Curr Biol 28:1703-1713.e6. CrossRef Medline

Marshel JH, Kaye AP, Nauhaus I, Callaway EM (2012) Anterior-posterior direction opponency in the superficial mouse lateral geniculate nucleus. Neuron 76:713-720. CrossRef Medline

Masri RA, Percival KA, Koizumi A, Martin PR, Grünert U (2016) Survey of retinal ganglion cell morphology in marmoset. J Comp Neurol. Advance online publication. Retrieved December 20, 2016. doi:10.1002/cne.24157.

Mauss AS, Vlasits A, Borst A, Feller M (2017) Visual circuits for direction selectivity. Annu Rev Neurosci 40:211-230. CrossRef Medline

Métin C, Godement P, Imbert M (1988) The primary visual cortex in the mouse: receptive field properties and functional organization. Exp Brain Res 69:594-612. Medline

Moritoh S, Komatsu Y, Yamamori T, Koizumi A (2013) Diversity of retinal ganglion cells identified by transient GFP transfection in organotypic tissue culture of adult marmoset monkey retina. PLoS One 8:e54667. CrossRef Medline

Niell CM, Stryker MP (2008) Highly selective receptive fields in mouse visual cortex. J Neurosci 28:7520-7536. CrossRef Medline

Osterhout JA, Stafford BK, Nguyen PL, Yoshihara Y, Huberman AD (2015) Contactin-4 mediates axon-target specificity and functional development of the accessory optic system. Neuron 86:985-999. CrossRef Medline

Peng YR, Tran NM, Krishnaswamy A, Kostadinov D, Martersteck EM, Sanes JR (2017) Satb1 regulates contactin 5 to pattern dendrites of a mammalian retinal ganglion Cell. Neuron 95:869-883.e6. CrossRef Medline

Percival KA, Koizumi A, Masri RA, Buzás P, Martin PR, Grünert U (2014) Identification of a pathway from the retina to koniocellular layer K1 in the lateral geniculate nucleus of marmoset. J Neurosci 34:3821-3825. CrossRef Medline

Percival KA, Venkataramani S, Smith RG, Taylor WR (2017) Directional excitatory input to direction-selective ganglion cells in the rabbit retina. J Comp Neurol. Advance online publication. Retrieved March 14, 2017. doi: $10.1002 / \mathrm{cne} .24207$.

Perry VH, Cowey A (1985) The ganglion cell and cone distributions in the monkey's retina: implications for central magnification factors. Vision Res 25:1795-1810. CrossRef Medline

Piscopo DM, El-Danaf RN, Huberman AD, Niell CM (2013) Diverse visual features encoded in mouse lateral geniculate nucleus. J Neurosci 33:46424656. CrossRef Medline

Priebe NJ, McGee AW (2014) Mouse vision as a gateway for understanding how experience shapes neural circuits. Front Neural Circuits 8:123. CrossRef Medline

Rivlin-Etzion M, Zhou K, Wei W, Elstrott J, Nguyen PL, Barres BA, Huberman AD, Feller MB (2011) Transgenic mice reveal unexpected diversity 
of on-off direction-selective retinal ganglion cell subtypes and brain structures involved in motion processing. J Neurosci 31:8760-8769. CrossRef Medline

Rodieck RW (1989) Starburst amacrine cells of the primate retina. J Comp Neurol 285:18-37. CrossRef Medline

Rodieck RW, Marshak DW (1992) Spatial density and distribution of choline acetyltransferase immunoreactive cells in human, macaque, and baboon retinas. J Comp Neurol 321:46-64. CrossRef Medline

Rodriguez AR, de Sevilla Müller LP, Brecha NC (2014) The RNA binding protein RBPMS is a selective marker of ganglion cells in the mammalian retina. J Comp Neurol 522:1411-1443. CrossRef Medline

Roska B, Werblin F (2001) Vertical interactions across ten parallel, stacked representations in the mammalian retina. Nature 410:583-587. CrossRef Medline

Rousso DL, Qiao M, Kagan RD, Yamagata M, Palmiter RD, Sanes JR (2016) Two pairs of ON and OFF retinal ganglion cells are defined by intersectional patterns of transcription factor expression. Cell Rep 15:1930-1944. CrossRef Medline

Sabbah S, Gemmer JA, Bhatia-Lin A, Manoff G, Castro G, Siegel JK, Jeffery N, Berson DM (2017) A retinal code for motion along the gravitational and body axes. Nature 546:492-497. CrossRef Medline

Sanes JR, Masland RH (2015) The types of retinal ganglion cells: current status and implications for neuronal classification. Annu Rev Neurosci 38:221-246. CrossRef Medline

Saul AB, Humphrey AL (1992) Evidence of input from lagged cells in the lateral geniculate nucleus to simple cells in cortical area 17 of the cat. J Neurophysiol 68:1190-1208. CrossRef Medline

Schiller PH, Finlay BL, Volman SF (1976) Quantitative studies of single-cell properties in monkey striate cortex. I. Spatiotemporal organization of receptive fields. J Neurophysiol 39:1288-1319. CrossRef Medline

Seabrook TA, Burbridge TJ, Crair MC, Huberman AD (2017) Architecture, function, and assembly of the mouse visual system. Annu Rev Neurosci 40:499-538. CrossRef Medline

Sheehan-Rooney K, Pálinkášová B, Eberhart JK, Dixon MJ (2010) A crossspecies analysis of Satb2 expression suggests deep conservation across vertebrate lineages. Dev Dyn 239:3481-3491. CrossRef Medline

Shinmyo Y, Tanaka S, Tsunoda S, Hosomichi K, Tajima A, Kawasaki H (2016) CRISPR/Cas9-mediated gene knockout in the mouse brain using in utero electroporation. Sci Rep 6:20611. CrossRef Medline

Silveira LCL, Perry VH (1991) The topography of magnocellular projecting ganglion cells (M-ganglion cells) in the primate retina. Neuroscience 40: 217-237. CrossRef Medline

Sinha R, Hoon M, Baudin J, Okawa H, Wong ROL, Rieke F (2017) Cellular and circuit mechanisms shaping the perceptual properties of the primate fovea. Cell 168:413-426.e12. CrossRef Medline

Sluch VM, Davis CH, Ranganathan V, Kerr JM, Krick K, Martin R, Berlinicke CA, Marsh-Armstrong N, Diamond JS, Mao HQ, Zack DJ (2015) Differentiation of human ESCs to retinal ganglion cells using a CRISPR engineered reporter cell line. Sci Rep 5:16595. CrossRef Medline

Stewart DL, Chow KL, Masland RH (1971) Receptive-field characteristics of lateral geniculate neurons in the rabbit. J Neurophysiol 34:139-147. CrossRef Medline

Sümbül U, Song S, McCulloch K, Becker M, Lin B, Sanes JR, Masland RH, Seung HS (2014) A genetic and computational approach to structurally classify neuronal types. Nat Commun 5:3512. CrossRef Medline

Swadlow HA, Weyand TG (1985) Receptive-field and axonal properties of neurons in the dorsal lateral geniculate nucleus of awake unparalyzed rabbits. J Neurophysiol 54:168-183. CrossRef Medline

Sweeney NT, James KN, Nistorica A, Lorig-Roach RM, Feldheim DA (2017) Expression of transcription factors divides retinal ganglion cells into distinct classes. J Comp Neurol. Advance online publication. Retrieved January 12, 2017. doi:10.1002/cne.24172.

Szmajda BA, Grünert U, Martin PR (2008) Retinal ganglion cell inputs to the koniocellular pathway. J Comp Neurol 510:251-268. CrossRef Medline

Tang JC, Szikra T, Kozorovitskiy Y, Teixiera M, Sabatini BL, Roska B, Cepko CL (2013) A nanobody-based system using fluorescent proteins as scaffolds for cell-specific gene manipulation. Cell 154:928-939. CrossRef Medline

Tang JC, Rudolph S, Dhande OS, Abraira VE, Choi S, Lapan SW, Drew IR, Drokhlyansky E, Huberman AD, Regehr WG, Cepko CL (2015) Cell type-specific manipulation with GFP-dependent cre recombinase. Nat Neurosci 18:1334-1341. CrossRef Medline

Taylor WR, Smith RG (2012) The role of starburst amacrine cells in visual signal processing. Vis Neurosci 29:73-81. CrossRef Medline

Ting JT, Kalmbach B, Chong P, de Frates R, Keene CD, Gwinn RP, Cobbs C, Ko AL, Ojemann JG, Ellenbogen RG, Koch C, Lein E (2018) A robust ex vivo experimental platform for molecular-genetic dissection of adult human neocortical cell types and circuits. Sci Rep 8:8407. CrossRef Medline

Vaney DI, Pow DV (2000) The dendritic architecture of the cholinergic plexus in the rabbit retina: selective labeling by glycine accumulation in the presence of sarcosine. J Comp Neurol 421:1-13. CrossRef Medline

Vaney DI, Sivyer B, Taylor WR (2012) Direction selectivity in the retina: symmetry and asymmetry in structure and function. Nat Rev Neurosci 13:194-208. CrossRef Medline

Völkner M, Zschätzsch M, Rostovskaya M, Overall RW, Busskamp V, Anastassiadis K, Karl MO (2016) Retinal organoids from pluripotent stem cells efficiently recapitulate retinogenesis. Stem Cell Reports 6:525-538. CrossRef Medline

Wässle H (2004) Parallel processing in the mammalian retina. Nat Rev Neurosci 5:747-757. CrossRef Medline

Wässle H, Riemann HJ (1978) The mosaic of nerve cells in the mammalian retina. Proc R Soc Lond B Biol Sci 200:441-461. CrossRef Medline

Wässle H, Peichl L, Boycott BB (1981) Dendritic territories of cat retinal ganglion cells. Nature 292:344-345. CrossRef Medline

Wässle H, Grünert U, Röhrenbeck J, Boycott BB (1989) Cortical magnification factor and the ganglion cell density of the primate retina. Nature 341:643-646. CrossRef Medline

Wei W (2018) Neural mechanisms of motion processing in the mammalian retina. Annu Rev Vis Sci 4:165-192. CrossRef Medline

Weng S, Sun W, He S (2005) Identification of ON-OFF direction-selective ganglion cells in the mouse retina. J Physiol 562:915-923. CrossRef Medline

White AJ, Solomon SG, Martin PR (2001) Spatial properties of koniocellular cells in the lateral geniculate nucleus of the marmoset Callithrix jacchus. J Physiol 533:519-535. CrossRef Medline

Wilson DE, Smith GB, Jacob AL, Walker T, Dimidschstein J, Fishell G, Fitzpatrick D (2017) GABAergic neurons in ferret visual cortex participate in functionally specific networks. Neuron 93:1058-1065.e4. CrossRef Medline

Xu X, Ichida J, Shostak Y, Bonds AB, Casagrande VA (2002) Are primate lateral geniculate nucleus (LGN) cells really sensitive to orientation or direction? Vis Neurosci 19:97-108. CrossRef Medline

Yamada ES, Bordt AS, Marshak DW (2005) Wide-field ganglion cells in macaque retinas. Vis Neurosci 22:383-393. CrossRef Medline

Yoshida K, Watanabe D, Ishikane H, Tachibana M, Pastan I, Nakanishi S (2001) A key role of starburst amacrine cells in originating retinal directional selectivity and optokinetic eye movement. Neuron 30:771-780. CrossRef Medline

Zhang C, Yu WQ, Hoshino A, Huang J, Rieke F, Reh TA, Wong ROL (2018) Development of ON and OFF cholinergic amacrine cells in the human fetal retina. J Comp Neurol. Advance online publication. Retrieved February 6, 2018. doi:10.1002/cne.24405.

Zhao X, Qu Z, Tickner J, Xu J, Dai K, Zhang X (2014) The role of SATB2 in skeletogenesis and human disease. Cytokine Growth Factor Rev 25:3544. CrossRef Medline 